\title{
Nejsou čáry jako čáry: Inkrementální linie v mikrostruktuře zubů a jejich využití při analýze kosterních nálezů
}

\section{Different lines of our lives: Incremental lines in the microstructure of teeth and their applications in the analysis of human remains}

\author{
Adela Hupková / Soňa Šáliová / Miroslav Králík / Róbert Malček
}

\begin{abstract}
Abstrakt
Buňky produkující tvrdé zubní tkáně zanechávají v průběhu vývoje zubů pod vlivem různých metabolických rytmů záznam o jejich aktivitě ve formě růstových markerů, označovaných jako inkrementální linie. Kromě těchto pravidelných časových markerů jsou v mikrostruktuře zubů zaznamenaná a po celou dobu existence zubu př́tomná také metabolická a fyziologická narušení způsobená stresovými událostmi. Cílem tohoto přispěvku je rekonstrukce vývojového záznamu ze zubů kosterního nálezu dítěte z ojedinělého hrobu na lokalitě Muráň-Hrad, Slovensko pomocí metody odontochronologie a také načrtnutí možných přínosů využití histologického přístupu a analýz výbrusů zubů v bioarcheologii při studiu minulých populací.
\end{abstract}

\section{Klíčová slova}

odontochronologie, histologie tvrdých zubních tkání, vývoj zubů, stres, akcentované linie, dožitý věk (chronologický)

\begin{abstract}
During the period of formation of the teeth, the cells that secrete dental hard tissues under various metabolic rhythms leave a record of their activity in the form of growth markers called incremental lines. Besides these regular time markers, in the microstructure of teeth metabolic and physiological disturbances caused by stressful events are permanently recorded and observable for as long as the tooth exists. The purpose of the present study was to apply odontochronological techniques in retrieval of a developmental record from dental remains of a child's skeleton from a solitary burial found in a site Muráň-Castle, Slovakia and to outline how bioarchaeology can beneficiate by including the histological approach and analysis of tooth sections in the study of past populations.
\end{abstract}

\section{Keywords}

odontochronology, dental hard tissue histology, dental development, stress, accentuated lines, (chronological) age at death

Příspěvek vznikl díky podpoře specifického výzkumu „Aplikace metod analýzy obrazu a tvaru v rutinním zpracování kosterních nálezů" (MUNI/A/0835/2012) a „Bioarcheologické metody pro komplexní hodnocení raně středověkých populací" (MUNI/A/0983/2013). 


\section{1. Úvod}

Periodické záznamy v tělních strukturách živých organizmů vznikají, když se plynulý, dlouhodobý růst nějaké trvanlivé biologické struktury kombinuje s periodickou (roční, měsíční, denní) změnou zevních podmínek, která ovlivňuje plynulost tohoto růstu. $\mathrm{V}$ dané struktuře pak vzniká záznam ve formě připomínající čárový kód, jehož nepravidelnosti lze využít k rekonstrukci a studiu událostí a faktorů, které $\mathrm{k}$ němu vedly. Velmi detailní periodický záznam se vytváří také ve struktuře zubů savců, včetně člověka. Vhledem $\mathrm{k}$ tomu, že se tvrdé zubní tkáně zachovávají i v tafonomicky nepříznivých podmínkách, představují bohatý zdroj informací o růstu každého jedince a jeho okolnostech, pozorovatelný i v dospělosti.

Cílem tohoto příspěvku je popsat principy, které činí z mikrostruktury zubní skloviny a dentinu předmět zájmu antropologie, ukázat jejich praktickou aplikaci na jednom prríkladu archeologicky odkrytého skeletu a diskutovat možnosti a limity využití odontochronologie v běžné praxi.

\section{Mikrostruktura tvrdých zubních tkání}

Formování tvrdých zubních tkání v průběhu vývoje a růstu zubů probíhá rytmickým zpo̊sobem, v periodicky se opakujících intervalech, což se v jejich mikrostruktuře projevuje vznikem charakteristických růstových markerů. Tyto přirůstkové, neboli inkrementálni struktury/ linie se často označují jako krátkodobé, vznikající v kratším časovém úseku 24 hodin, a dlouhodobé, vznikající v delší periodě. Struktury v zubní sklovině a v dentinu si přitom vzájemně odpovídají, i když jejich rozlišení a studium v dentinu je obtížnější. Denní přírůstky v prizmatické sklovině se označují jako přcičné linie a v dentinu jako von Ebnerovy linie. Dlouhodobější přírůstky (s individuálně konzistentní, ale vnitro- a mezidruhově variabilní periodicitou $)^{1}$ ve sklovině jsou známé jako Retziusovy linie a v dentinu pak jako Andresenowy linie (obrázek 1). Na vnějším povrchu zubu se dlouhodobé linie manifestují (zejména u juvenilních jedinců před ohlazením/ opotřebením povrchu skloviny) jako perikymata na povrchu korunky a periradikulárni proužky na povrchu kořene (Dean 2000; Smith 2008; Smith - Tafforeau 2008; FitzGerald - Rose 2008; Hillson 2014). Zubní cement je produkován v mnohem pomalejším rytmu, přičemž aktivita cementoblastů by mohla být ovlivněna sezónními změnami, jak naznačují studie u zvířat (Lieberman 1993, 1994). V mikrostruktuře zubního cementu jsou pak patrné prstencovité struktury označované jako př́růstky zubniho cementu, jejichž periodicita odpovídá ročním růstovým intervalům (Naylor et al. 1985; Smith 2008).

Ameloblasty produkující sklovinu i odontoblasty produkující dentin jsou při sekreci organické matrix ovlivňovány metabolickými událostmi, které mohou způsobit změny v rychlosti sekrece nebo ve struktuře matrix, v extrémních situacích dokonce jejich předčasnou smrt. Pozměněná nebo nekompletní matrix následně mineralizuje, čímž dochází k trvalému záznamu metabolických událostí do mikrostruktury skloviny a dentinu (Dean - Elamin 2014). Narušení vývoje v důsledku působení stresu se v mikrostruktuře tvrdých zubních tkání projeví vznikem tenkých vrstev s abnormální strukturou, které označují pozici aktivních buněk v průběhu stresové události. Na výbrusech zubů jsou patrné v podobě zesílených, akcentovaných linii (stresových linii), a to jak ve sklovině, tak i v dentinu (Dean 2000; Smith 2008; Smith - Tafforeau 2008; FitzGerald Rose 2008; Hillson 2014). Jelikož se tyto události a vývojová narušení objevují ve vývoji v určitém čase, jsou zaznamenány v mikrostruktuře všech zubů, které se v čase působení stresové události vyvíjely (Dirks et al. 2002; Schwartz - Dean 2008; 


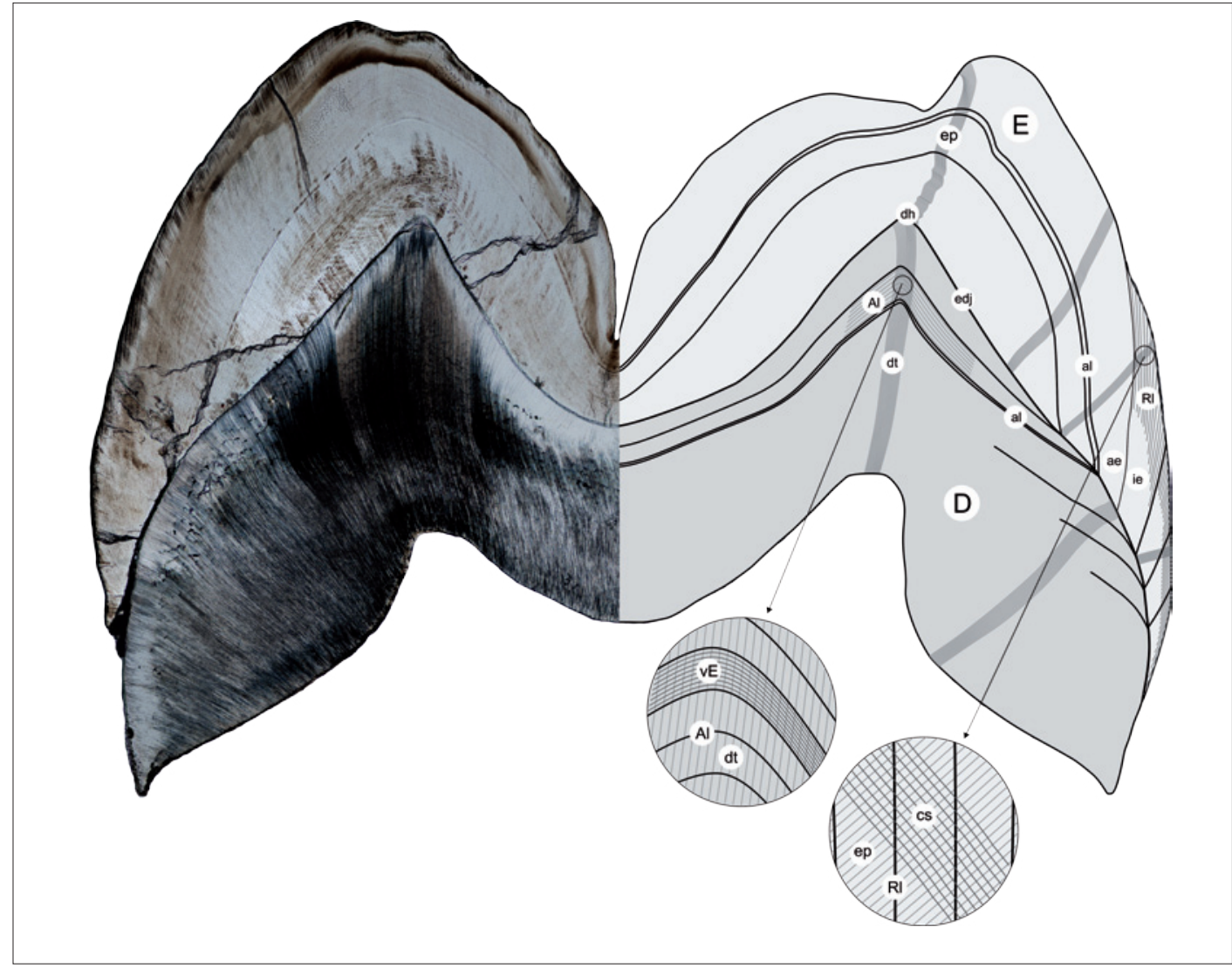

Obr. 1. Histologický výbrus rostoucího lidského zubu (třetí horní stolička pravé strany) zobrazený v procházejícím světle pomocí světelného mikroskopu (část vlevo) a schematické znázornění vnitřní mikrostruktury a inkrementálních linií (část vpravo): $E$ - sklovina, D - dentin, edj - dentino-sklovinná hranice, $d h$ - dentinový hrot, ep - sklovinná prizmata, $d t$ - dentinové tubuly, ae - apoziční/hrbolková sklovina, ie - imbrikační/laterální sklovina, $R l$ - Retziusovy linie, Al - Andresenovy linie, cs - příčné linie, vE - von Ebnerovy linie, al - akcentované/ stresové linie.

Fig. 1. Histological thin section of the growing human tooth (right third upper molar) imaged in transmitted light using a conventional light microscopy (on the left) and schematic of internal microstructure and incremental lines (on the right): $E$ - enamel, $D$ - dentine, edj-enamel-dentine junction, $d h$ - dentine horn, ep - prism boundaries, $d t$ - dentine tubules, ae - appositional/cuspal enamel, ie - imbricational/lateral enamel, Rl - Retzius lines, $A l$ - Andresen lines, cs - prism cross-striations, $v E$ - von Ebner's lines, al - accentuated/stress lines.

FitzGerald - Rose 2008; Hillson 2014). I když je identifikováno několik faktorů způsobujících vznik stresových linií (např. strádání a podvýživa, horečnatá a infekční onemocnění, vakcinace), u neznámých kosterních pozůstatků jde vždy o nespecifické markery stresu stěží spojitelné s konkrétními prŕícinami (Dean - Elamin 2014;
Birch - Dean 2014). Výjimku představuje specifická akcentovaná linie nacházející se u všech již prenatálně se vyvíjejících zubů (u člověka všechny dočasné zuby a většinou první trvalá stolička), tzv. neonatálni linie, která odděluje prenatálně a postnatálně formovanou část zubu a označuje událost narození (Hillson 2014). 


\section{Princip odontochronologie}

Jedinečný způsob vývoje a růstu zubů a citlivá reakce ameloblastů a odontoblastů na působení stresu a změny v průběhu vývoje umožňuje vznik trvalého záznamu vývojových událostí v jejich mikrostruktuře, přítomného po celou dobu existence zubu. Pomocí mikroskopických analýz růstových markerů viditelných na histologických výbrusech zubů (obrázek 1) lze denní a vícedenní přírůstky ve sklovině a dentinu kvantifikovat, tj. lze zjistit, jak dlouho trvalo formování př́slušné části zubu. Také lze zjistit, kdy v průběhu formování zubu došlo ke vzniku abnormálních inkrementů, indikujících nějakou metabolickou změnu aktivních buněk, která ovlivnila inkrementy vznikající v té době. Protože se jednotlivé zuby v chrupu vyvíjejí v překrývající se sekvenci, akcentované linie mohou být využity jako registrační místa - postupným přecházením od dříve k později se vyvíjejícím zubům může být vytvořena rozšířená sekvence zachycující vývoj celé dentice. Neonatální linie pak umožňuje její zasazení do chronologického rámce lidského života. Ontogenetický záznam v zubní sklovině a dentinu tedy lze rekonstruovat až s přesností na týdny a dny (Beynon et al. 1998; Smith 2008; Antoine - Hillson - Dean 2009; Birch - Dean 2014). U nedospělých jedinců s neukončeným vývojem chrupu může být sekvence akcentovaných linií končící posledními inkrementy na nejméně vyvinutém zubu použita pro odhad chronologického věku v čase smrti (Dean - Beynon 1991; Dirks 1998; Reid - Beynon - Rozzi 1998; Thomas 2003; Smith - Reid - Sirianni 2006; Smith 2008; FitzGerald - Rose 2008; FitzGerald - Hillson 2009; Schwartz - Dean 2008; Antoine - Hillson - Dean 2009; Hillson 2014).

$\mathrm{V}$ další části se pokusíme ukázat praktickou aplikaci celé metody na prrípadové studii a následně komentovat její výhody, nevýhody a odlišnosti od obvykle používaných metod od- hadu věku u nedospělých jedinců a hodnocení stresových událostí podle zubů.

\section{Př́padová studie}

V rámci průběžného záchranného archeologického výzkumu (Archeologický ústav Slovenské akademie věd) lokality Muráň-Hrad, která se nachází v katastru obce Muráň v okresu Revúca (Banskobystrický kraj, Slovensko), byl v roce 2013 odkrytý izolovaný kosterní hrob a vyzdviženy lidské kosterní pozůstatky nedospělého jedince (obrázek 2). Ve stejné vrstvě se nacházela os lunatum tura domácího. Kosterní pozůstatky byly uloženy v natažené poloze na zádech s náznakem hrobové jámy, bez milodarů, dolní čelist jedince byla přesunutá nad horní část lebky. Pozůstatky se nacházely v sídlištní vrstvě, ve které se našly keramické střepy datující vrstvu do mladší nebo pozdní doby bronzové (pilinská/kyjatická kultura), překryté byly novověkou dlažbou. Je nepravděpodobné, že by pozůstatky pocházely z doby renesanční či barokní, způsob pohřbu však není typický ani pro mladší a pozdní dobu bronzovou (Malček - Šimkovic 2013). Vzhledem k nálezovým okolnostem hrob nelze archeologicky (kontextem) jednoznačně datovat a mohl by patřit všem zmíněným fázím osídlení, v každé z nich by však představoval výjimečný nález. Jelikož v kyjatické kultuře byl obvyklým způsobem nakládání s mrtvým žeh, přičemž se pohřbívalo na vyhrazených místech mimo sídlišst (na pohřebištích), mohlo by jít o nestandardní pohřeb. Ve vrcholném středověku či novověku se sice pohřbívalo kostrově, opět ale na vyhrazených místech (hřbitovech) v blízkosti církevní stavby (kostel nebo alespoň kaple). Taková se však v blízkém okolí tohoto dětského hrobu nenachází. Stěží si taky lze představit, že by jedince pohřbili při nároží hlavního paláce hradu. V každém případě patří celý region k nejméně archeologicky prozkou- 


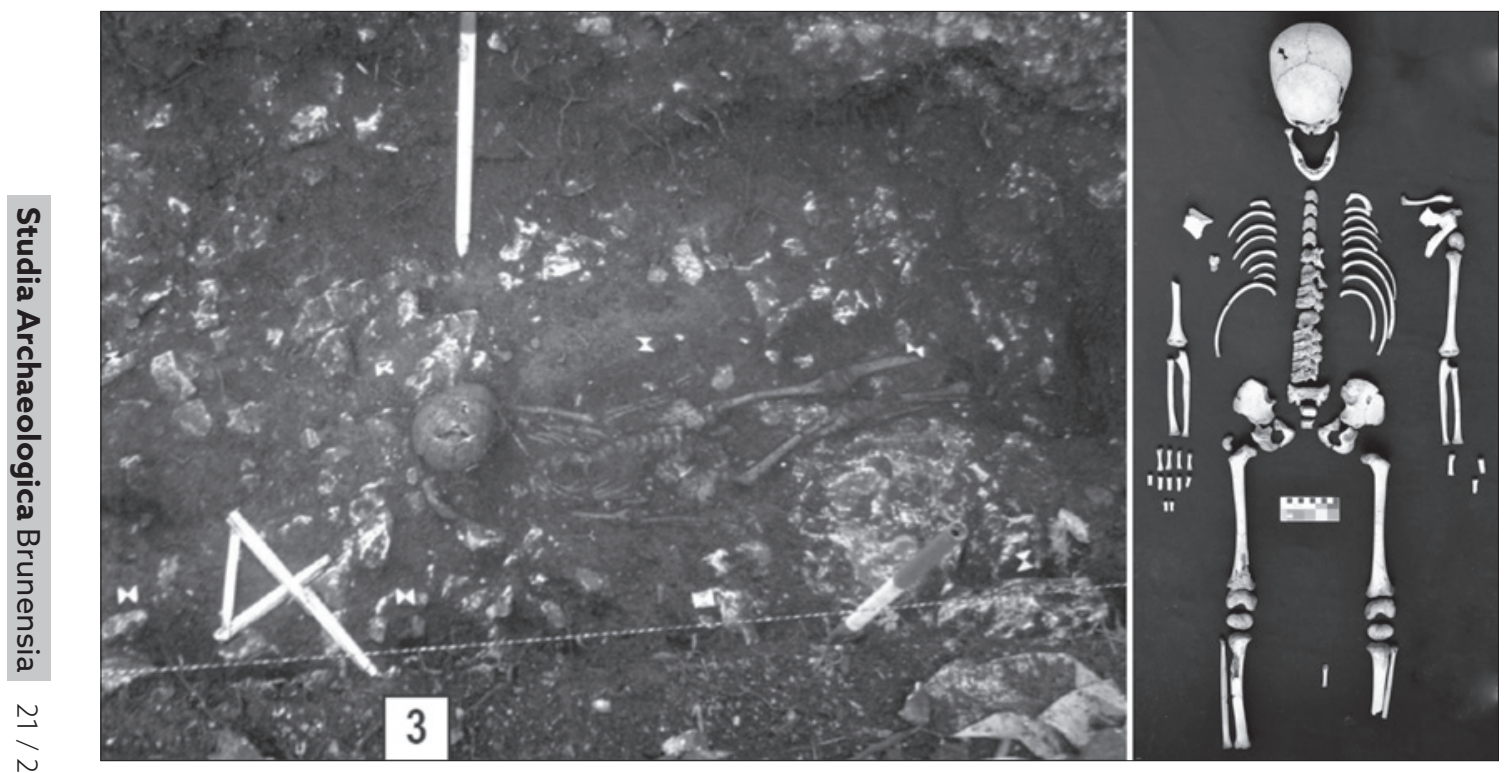

Obr. 2. Vlevo nálezová situace (Malček - Šimkovic 2013); vpravo očištěná kostra dítěte z lokality Muráň-Hrad, Slovensko (Foto: Soňa Šáliová).

Fig. 2. On the left archaeological situation (Malček - Šimkovic 2013); on the right cleaned skeleton of child from the site Muráň-Castle, Slovakia (Photo: Soňa Šáliová).

maným oblastem Slovenska a tento nález představuje jeden z prvních (jestli ne vůbec první) tamějších podrobně analyzovaných nálezů lidských kosterních pozůstatků.

Skelet jedince je téměř kompletní, chybí distální konce kostí bérce z levé strany a kosti obou nohou. Zachovala se téměř celá lebka a větši část postkraniálního skeletu, i když ve fragmentárním stavu. Na skeletu dítěte nebyly pozorovány žádné patologie nebo zranění.

Cílem této případové studie byla rekonstrukce vývoje zubů, překonaných stresových událostí a odhadu dožitého věku (chronologického) pomocí metody odontochronologie, tj. mikroskopické analýzy růstových markerů a indikátorů stresu pozorovatelných na histologických výbrusech zubů. Detailní histologická analýza zubů tohoto jedince byla motivována přítomností makroskopicky pozorovatelných indikátorů stresu (hypoplastické změny zubní skloviny předních zubů, náznak cribra orbitalia $\mathrm{v}$ pravé očnici), ale také nepřítomností Harrisových linií na rentgenových snímcích kostí končetin/kostí typu dlouhého, jež se rovněž používají jako indikátory stresu při rekonstrukci životních podmínek minulých populací (Larsen 2002). Jelikož jde o neobvyklý nález dětského hrobu, bylo naším cílem také zjistit, zda není neobvyklý způsob pohřbení spojen s neobvyklým záznamem stresových událostí v zubech v období nedlouho před smrtí.

\subsection{Př́prava výbrusů}

Dentice zkoumaného jedince je smíšená, se začínající resorpcí kořenů u dočasných zubů a částečně vyvinutými všemi trvalými zuby (kromě poslední stoličky). V kryptách (uzavřených v čelistech) se z horních trvalých zubů zachovaly oba druhé řezáky, oba špičáky, všechny čtyři 
zuby třenové a levá druhá stolička (FDI kódy²12, 22, 13, 23, 14, 24, 15, 25 a 27); z dolních zubů oba špičáky, všechny čtyři zuby třenové a pravá i levá druhá stolička (FDI kódy 33, 43, 34, 44, $35,45,37$ a 47). Z prořezaných zubů v okluzi byly nalezeny z horních dočasných zubů pravý špičák a všechny čtyři stoličky, z trvalých zubů pravý střední řezák a obě první stoličky (FDI kódy 53, 54, 64, 55, 65, 11, 16 a 26); z dolních zubů byla nalezena jen pravá a levá druhá dočasná stolička (FDI kódy 75 a 85).

Histologické výbrusy byly připraveny ze dvou dočasných (FDI kódy 65, 75) a šesti trvalých zubů (FDI kódy 11, 12, 33, 26, 27, 47). Pravá i levá strana obou čelistí byly radiologicky vyšetřeny a všechny zuby vybrané pro histologickou analýzu byly před přípravou výbrusů jemně očišstěny a fotograficky zdokumentovány; zhotoveny také byly jejich fyzické repliky z dentální sádry. Za účelem zpřesnění orientace řezu a zhotovení výbrusů v optimální rovině přes hroty dentinu (v labiolinguální rovině středem korunky u jednokořenových zubů a $\mathrm{v}$ bukolinguální rovině přes mesiální a distální hrbolky u stoliček) byla na všech zubech vyznačena grafitovou tužkou rovina řezu.

Výbrusy byly zhotoveny v brusírně na Ústavu geologických věd Přírodovědecké fakulty Masarykovy univerzity. Všechny zuby byly před řezáním zality do epoxidové pryskyřice (Araldite 2020) kvůli zvýšení jejich mechanické odolnosti. Longitudinální výřezy o tlouštce přibližně $1 \mathrm{~mm}$ byly zhotoveny pomocí řezacího zařízení s diamantovým řezným kotoučem (StruersDiscoplan-TS, řezný kotouč $200 \mu \mathrm{m}$ ). Výřezy byly dále broušeny, leštěny a lapovány na výbrusy o finální tlouštce přibližně $100 \mu \mathrm{m}$ pomocí brusky/leštičky StruersLaboPol 21 a ručně na skleněné desce s abrazivní suspenzí, následně ultrazvukově očištěny, dehydrovány v alkoholu a zakryty krycím sklíčkem pomocí kanadského balzámu.

\subsection{Mikroskopie, analýza obrazu a způsob měření}

Histologické výbrusy byly pozorovány v procházejícím světle pomocí světelného mikroskopu Nikon Eclipse 50i s polarizací, vybaveného okulárem se zvětšením 10× a objektivy se zvětšením $2 \times, 4 \times, 10 \times, 20 \times$ a $40 \times$. Mikrofotografie byly zaznamenávány pomocí barevné digitální kamery Nikon DS-Fil, 5.0 Mega Pixel propojené s mikroskopem v kombinaci s programem pro analýzu obrazu NIS-Elements 3.0. Různé struktury byly studovány a fotograficky zaznamenány při různém zvětšení. Akcentované linie byly identifikovány na snímcích zhotovených při zvětšení 40×, vzdálenosti mezi liniemi byly měřeny podél sklovinných prizmat a dentinových tubulů při zvětšení 100× a denní př́írůstky mezi příčnými a von Ebnerovými liniemi při zvětšení 400×. Fotomontáže celého zubního výbrusu a vybraných částí skloviny a dentinu byly vytvořeny v programu Adobe Photoshop CS4 ze snímků zhotovených při zvětšení 40× a 100×. Všechna měření byla realizována v programu SigmaScan Pro 5.0.

Ve všech analyzovaných zubech byly ve sklovině korunek a dentinu rostoucích kořenů nejdříve identifikovány akcentované linie (podle doporučení uvedených v práci FitzGerald Saunders 2005). Doba formování příslušné části zubu pak byla určována na základě měření denních př́růstků mezi dvěma sousedními akcentovanými liniemi a ne jejich přímým počítáním z důvodů nemožnosti stanovení jejich kompletního počtu (Dirks et al. 2010; Dirks - Bromage - Agenbroad 2012). V korunce byla podél sklovinných prizmat měřena nejdříve vzdálenost od dentino-sklovinné hranice k první akcentované linii (v blízkosti dentinového hrotu) a následně od okraje jedné akcentované linie po okraj následující - z důvodu zvýšení přesnosti měření na dvou různých místech - v oblasti s nejlépe viditelnými trajektoriemi prizmat a denních pří- 


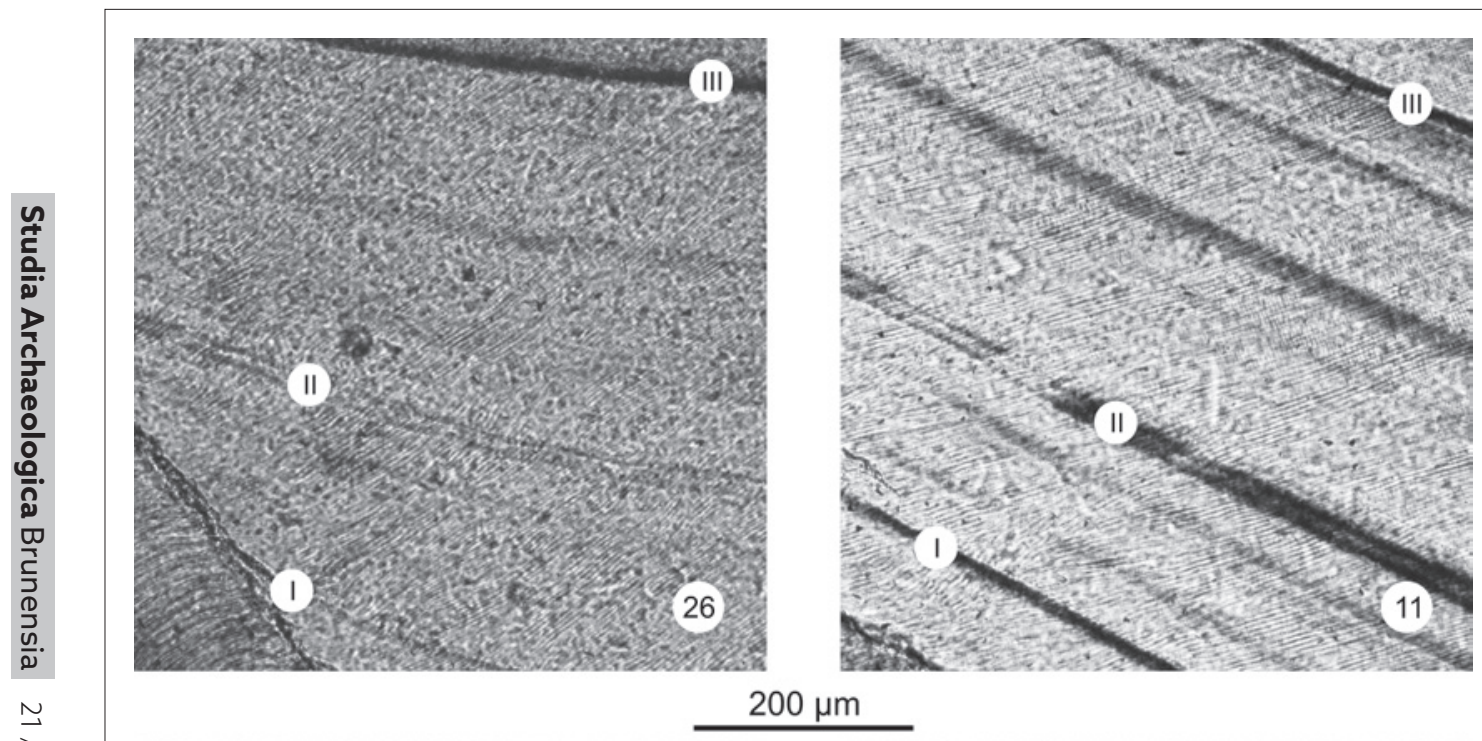

금
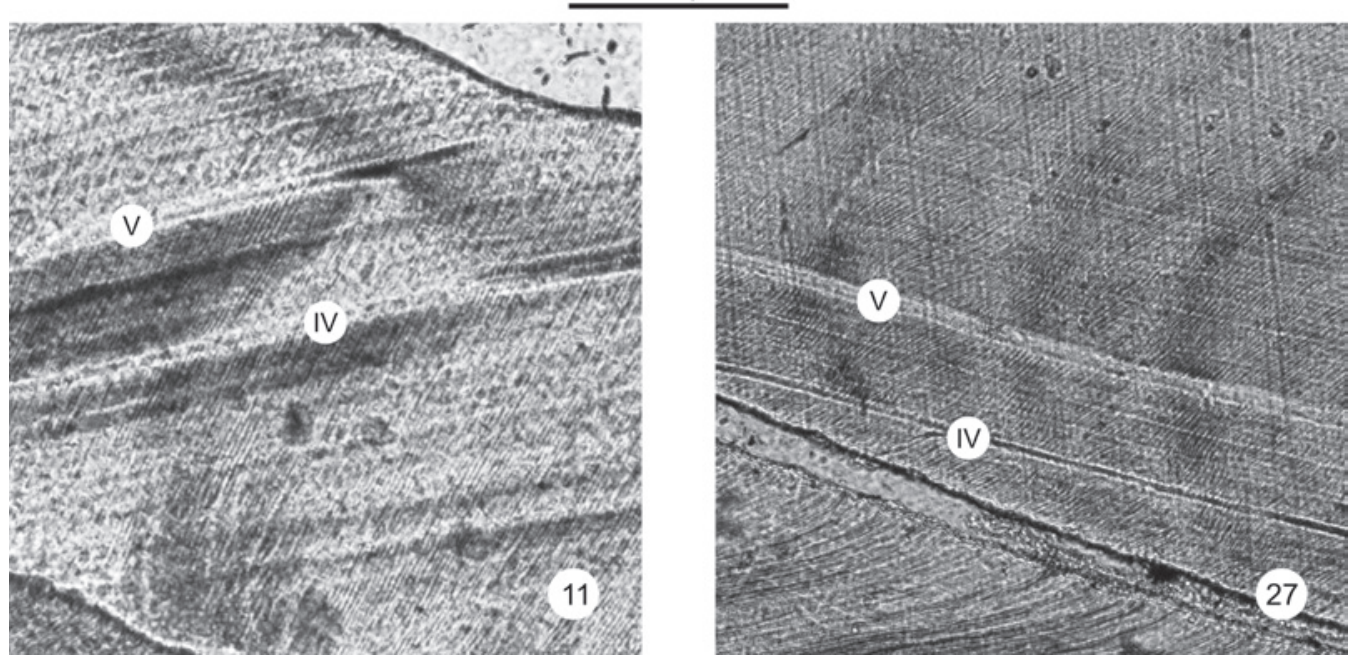

Obr. 3. Ukázka překryvu akcentovaných linií (značky I, II, III, IV, V) mezi rưznými zuby (kódy FDI 26, 11, 27). Linie IV a V jsou na povrchu korunky řezáku spojeny s hypoplastickými defekty, zatímco u druhé stoličky jsou ukryty hluboce v hrbolkové sklovině (viz obr. 1).

Fig. 3. Example of an overlap of subsequent accentuated lines (I, II, III, IV, V) among different teeth (FDI codes $26,11,27)$. Lines IV and $V$ are associated with hypoplastic defect on the incisor crown surface, whereas in the second molar, they are burried deeply in cuspal enamel.

růstků a v průsečíku akcentované linie s denti- márně byly měřeny dvojice nebo skupinky po no-sklovinnou hranicî̉. Tato vzdálenost pak byla sobě jdoucích denních př́růstků oddělených vydělena mírou denní sekrece co nejblíže měře- příčnými liniemi a jejich celková délka byla né oblasti. Denní míra sekrece byla vypočtena vydělena jejich celkovým počtem). U druhých jako průměrná hodnota z několika měření (pri- trvalých stoliček byla poslední akcentovaná linie 
ve sklovině identifikována také v dentinu a následně stanovena doba formování zubu mezi ní a posledním inkrementem rostoucího kořene. Měřena byla vzdálenost mezi sousedními akcentovanými liniemi podél dentinových tubulů od průsečíku linie s dentino-sklovinnou nebo dentino-cementovou hranici až po okraj následující linie. Změřená vzdálenost pak byla vydělena průměrnou hodnotou míry denní sekrece v dentinu co nejblíže měřené oblasti. U všech analyzovaných zubů byla určena periodicita denních prŕrůstků mezi sousedními dlouhodobými inkrementálními strukturami a to tak, že ve sklovině laterální části korunky se zřetelnými dlouhodobými přírůstky (perikymata na povrchu zubu) byl získaný počet dnů mezi dvěma označenými liniemi vydělený počtem dlouhodobých přírůstků. Pro každý zub byly získány dva číselné údaje ze dvou různých oblastí odpovídající intervalům mezi dvěma stresovými událostmi, přičemž pro další analýzy byl počet dnů mezi dvěma liniemi z prvního a druhého měření zprůměrován. Intervaly mezi akcentovanými liniemi pak byly použity pro ověření překryvu stresových událostí mezi různými zuby (obrázek 3) od nejvíce zformovaných (dočasné zuby, první trvalá stolička) po nejméně zformované zuby (druhé trvalé stoličky) a vytvoření rozšířené sekvence akcentovaných linií. Pro další výpočty byl použitý průměrný interval ze všech zubů, ve kterých byl daný chronologický úsek zaznamenaný ${ }^{4}$ V oblasti laterální části korunky byla pro výpočet doby formování korunky využita periodicita a počet dlouhodobých inkrementálních linií. Díky rozšîrené sekvenci stresových linií bylo možno rekonstruovat chronologii zubniho vývoje (délka formování korunky, věk v čase iniciace a ukončení růstu korunky), sestavit časováni stresových událostí a odhadnout dožitý (chronologický) věk. Věk v čase smrti byl počítán od neonatální linie, která odděluje prenatálně a postnatálně formovanou část zubu a označuje událost narození.

\subsection{Výsledky}

\subsubsection{Chronologie zubního vývoje}

U sledovaného jedince je dentice smíšená u dočasných zubů již započala resorpce kořenů, u všech trvalých zubů (kromě poslední stoličky) jsou korunky plně vyvinuty a kořeny $\mathrm{v}$ různém stupni vývoje. Při srovnání s moderními standardy mineralizace a erupce zubů vývoj dentice sledovaného jedince $\mathrm{z}$ hlediska kombinace vývoje jednotlivých zubů nespadal plně ani do jednoho z aplikovaných schémat (Schour - Massler 1941; Moorrees - Fanning - Hunt 1963a,b; Ubelaker 1999, cit. White - Black - Folkens 2011; AlQahtani - Hector - Liversidge 2010).

Mikroskopické analýze byly podrobeny dva dočasné (FDI kódy 65, 75) a šest trvalých zubů (FDI kódy 11, 12, 33, 26, 27, 47). Identifikace neonatální linie zaznamenávající události kolem narození spolu s překryvem následujících akcentovaných linií umožnily stanovit chronologii jejich vývoje (obrázek 4). Dlouhodobé inkrementální struktury se formovaly s periodicitou 7 dní, tj. v týdenních intervalech, což v rozpětí hodnot uváděných pro člověka představuje hodnotu nižší (Smith - Martin - Leakey 2003; Reid - Ferrell 2006; Reid - Dean 2006). Věk v čase iniciace růstu korunky, délka formování korunky a věk v čase ukončení růstu korunky jsou shrnuty v tabulce 1. Délka formování korunky druhé dolní dočasné stoličky (mesiolinguální hrbolek/ metaconid) odpovídá publikovaným hodnotám (Mahoney 2011) jak z hlediska formování v prenatálním období (54 dní), tak i v postnatálním období (300 dní). Vývoj druhé horní dočasné stoličky začal dříve a při narození byla zformována větší část jak hrbolku mesiobukálního/ protoconid (114 dní), tak i mesiolinguálního/ metaconid (105 dní). Délka formování korunky horních trvalých zubů, kromě druhé stoličky, je ve srovnání s publikovanými daty (Reid - Dean 2006; Hillson 2014) u sledovaného jedince spíše 


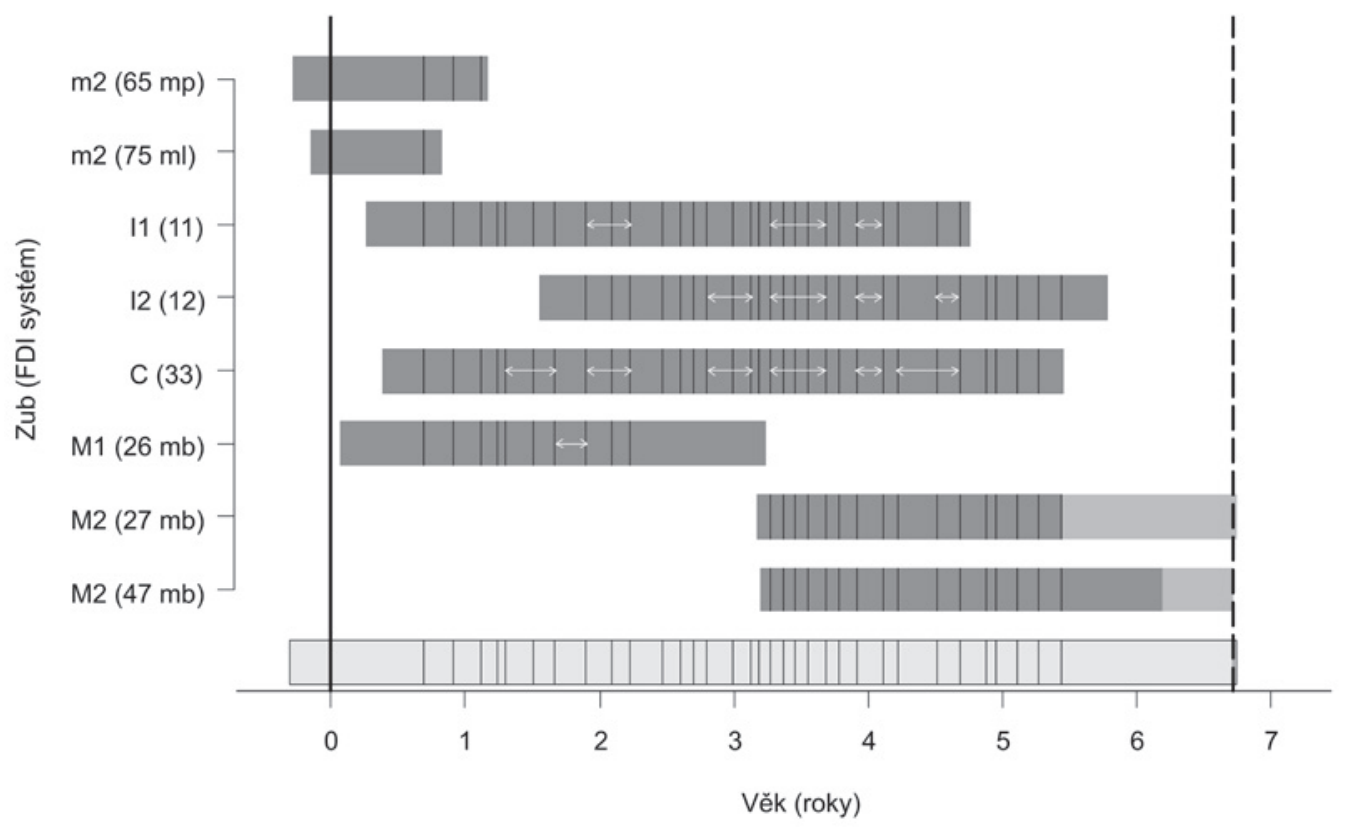

Legenda

Formování korunky

Formováni kơ̌ene

Hypoplázie

Rozšî́ená sekvence

| Narození

Stres

ismrt

Obr. 4. Kompozitní graf chronologie zubního vývoje, časování stresových událostí a odhadu dožitého věku jedince z lokality Muráň-Hrad, Slovensko, získaných pomocí metody odontochronologie. Znázornění délky formování korunky a věku v čase iniciace a ukončení růstu korunky. Záznam pozorovaných hypoplastických změn na povrchu skloviny, záznam nejvýraznějších akcentovaných linií, jejich časové zařazení a překryv mezi souběžně se vyvijejícími zuby. Rož̌iřená sekvence zachytává vývoj jedince v prenatálním období a postnatálním období až po zastavení růstu zubů z důvodu smrti. Zkratky mb, mp a ml označují mesiobukální, mesiopalatinální a mesiolinguální hrbolky stoliček.

Fig. 4. Composite graph of chronology of dental development, timing of stressful events and age at death assessment for the skeleton of the child from the site Muráň-Castle, Slovakia retrieved using method of odontochronology. Bar charts illustrate crown formation times, ages at initiation and completion of crown formation. Ages for the hypoplastic defects observable on crown surface and ages for the most prominent accentuated lines are plotted against bar charts illustrating also cross-match of the patterns of accentuated lines among teeth. Extended sequence records development of this individual during prenatal and postnatal period until the ending of teeth growth by reason of death. Vertical axis: Tooth (FDI system, abbreviations $m b, m p$ and $m l$ represent mesiobuccal, mesiopalatal and mesiolingual cusps in molars); horizontal axis: Age (years). Legend: dark grey - crown formation, grey - root formation, white double-headed arrow - hypoplastic defect, light grey - extended sequence, bold solid line - birth, solid line - stress, dash line - death. 


\begin{tabular}{|c|c|c|c|}
\hline $\begin{array}{c}\text { Zub } \\
\text { (systém FDI) }\end{array}$ & $\begin{array}{c}\text { Věk } \mathbf{v} \text { čase iniciace } \\
\text { růstu korunky (roky) }\end{array}$ & $\begin{array}{c}\text { Délka formování } \\
\text { korunky (roky) }\end{array}$ & $\begin{array}{c}\text { Věk v čase ukončení růstu } \\
\text { korunky (roky) }\end{array}$ \\
\hline $\mathrm{m} 2(65 \mathrm{mb})$ & $-0,31$ & 1,09 & 0,78 \\
\hline $\mathrm{m} 2(65 \mathrm{mp})$ & $-0,29$ & 1,45 & 1,16 \\
\hline $\mathrm{m} 2(75 \mathrm{ml})$ & $-0,15$ & 0,97 & 0,82 \\
\hline $11(11)$ & 0,26 & 4,50 & 4,76 \\
\hline $12(12)$ & 1,56 & 4,23 & 5,79 \\
\hline $\mathrm{C}(33)$ & 0,38 & 5,07 & 5,45 \\
\hline$M 1(26 \mathrm{mb})$ & 0,07 & 3,17 & 3,23 \\
\hline$M 1(26 \mathrm{mp})$ & 0,10 & 3,06 & 5,16 \\
\hline$M 2(27 \mathrm{mb})$ & 3,18 & $* 2,27$ & 6,14 \\
\hline$M 2(27 \mathrm{db})$ & 3,38 & 2,76 & 6,20 \\
\hline$M 2(47 \mathrm{mb})$ & 3,20 & 3,00 & 5,98 \\
\hline$M 2(47 \mathrm{ml})$ & 3,39 & 2,59 & \\
\hline
\end{tabular}

Tab. 1. Chronologie zubního vývoje dítěte z lokality Muráň-Hrad, Slovensko, získaná pomocí metody odontochronologie. Zkratky $m b, m p, m l$ a db označují hrbolky stoliček ( $m b$ - mesiobukální, mp - mesiopalatinální, $m l$ - mesiolinguální, db - distobukální); * značí odhad z důvodu poškození cervikální oblasti zubu.

Tab. 1. Chronology of dental development of the child from the site Muráň-Castle, Slovakia obtained using the method of odontochronology. First column: Tooth (FDI system; abbreviations $m b, m p, m l$ and $d b$ represent mesiobuccal, mesiopalatal, mesiolingual and distobuccal cusps in molars). Second column: Age at initiation of crown formation in years. Third column: Crown formation times in years; asterisk indicates estimation due to broken cervical region. Fourth column: Age at completion in years.

delší, tj. vývoj korunek je pomalejší; u druhé horní stoličky a dolních trvalých zubů se však hodnoty více blíží dolní hranici uváděného rozpětí hodnot. Iniciace růstu první trvalé stoličky se často objevuje před narozením, u tohoto jedince však začala až koncem prvního měsíce postnatálního života. Rovněž u ostatních zubů s výjimkou prvního horního řezáku a dolního špičáku se iniciace růstu objevuje o něco později, stále však v rozpětí publikovaných hodnot pro člověka (přehled v Hillson 2014); v případě druhého řezáku však růst korunky začal až o půl roku později.

\subsection{2 Časování stresových událostí}

Mikroskopická analýza hodnocených zubů pokrývajících vývoj jedince od narození až po smrt odhalila více než 30 akcentovaných linií (obrázek 4). Věk v čase vytvoření jednotlivých akcentovaných linií spolu s odhadem dožitého věku jsou uvedeny v tabulce 2 . Neonatální linie zaznamenávající události kolem narození byla identifikována jen u dočasných stoliček. V průběhu prvního roku postnatálního života byly nejvýraznější akcentované linie zjištěny v období 8 . až 11. měsíce. Ve druhém roce byla pozorovaná vyšší frekvence stresových událostí, ve věku 2 a 3,5 let pak jedinec prožil déletrvající období stresu, které se na povrchu korunek předních zubů projevilo ve formě hypoplastických defektů. Další velmi výrazné akcentované linie byly zjištěny kolem věku 4,5 roku. $\mathrm{V}$ posledním roce až roce a půl života nebyly v dentinu pozorovány žádné akcentované linie srovnatelné s liniemi z prvních čtyř let života. Vyloučit však nelze postmortální ztrátu posledně formované, nej- 
méně mineralizované tkáně v důsledku postdepozičních procesů, která by mohla představovat období dvou až pěti týdnů před smrtí (Antoine - Hillson - Dean 2009).

Zjištěné výsledky naznačují, že jedinec byl v průběhu života opakovaně vystavený stresovým faktorům ovlivňujícím formování tvrdých zubních tkání, i když jejich příčinu kromě neonatální linie nelze bez medicínské dokumentace blíže určit. Nepřítomnost Harrisových linií na rentgenových snímcích dlouhých kostí naznačuje, že vznikají pod vlivem jiných faktorů, než které souvisí se vznikem stresových markerů v mikrostruktuře zubů. Také je možné, že jsou projevem normálního růstu a růstového spurtu spíše než nutričního nebo patologického stresu (Papageorgopoulou et al. 2011). Ohledně náznaku cribra orbitalia v pravé očnici, histologická analýza kostní tkáně by mohla přinést informace o tom, zda jde skutečně o indikaci zhoršeného zdravotního stavu (nejen z důvodu anémie, jelikož etiologie cribra orbitalia je stále nejasná) nebo jen o postmortální změny a tedy pseudopatologii (Wapler - Crubézy - Schultz 2004).

\subsubsection{Odhad dožitého věku}

Standardními antropologickými metodami ${ }^{5}$ pro odhad věku nedospělých jedinců na základě vývoje dentice (mineralizace a erupce zubů) byl zubní věk jedince stanoven na 7-8 let podle vývojového schématu Schouera a Masslera (Schour - Massler 1941); na 7-8 let s rozpětím \pm 2 roky podle Ubelakerova modifikovaného schématu (Ubelaker 1999, cit. White - Black Folkens 2011); a 7,5 let podle londýnského Atlasu vývoje a erupce zubů (AlQahtani - Hector - Liversidge 2010), jak však již bylo uvedeno výše, podle vývoje jednotlivých zubů nespadal jedinec plně ani do jednoho z uvedených schémat. Podle Moorrees - Fanning - Huntovy metody hodnotící mineralizaci zubů (Moo- rrees - Fanning - Hunt 1963a,b) byl zubní věk jedince stanoven na 5,5-8,5 roku, v průměru 6,5 let (z 8 zubů). Kosterní věk byl podle osifikace kostry stanoven na 7-11 let (Schaefer Black - Scheuer 2009) a podle délky diafýz kostí typu dlouhého na 7-8 let (Stloukal - Hanáková 1978, cit. Dobisiková 1999) ${ }^{6}$. Identifikace neonatální linie, rozširřená sekvence z překrývajících se akcentovaných linií a částečně zformovaný kořen druhých stoliček umožnily odhad chronologického věku v čase smrti. I když všechny trvalé zuby jedince měly kořen s neukončeným vývojem a teoreticky pro odhad dožitého věku stačily dva zuby (např. dočasný zub s neonatální linií a jeden z nejdříve se vyvíjejících trvalých zubů), kvůli značnému tafonomickému poškození kořenového dentinu bylo pro zvýšení přesnosti měření použito více zubů (tabulka 2). Nutno však říct, že nebyla hodnocena ani intra- ani inter-individuální chyba měření. Pomocí provedených histologických analýz byl dožitý věk stanoven na 6,7 roku. Při zohlednění individuálních měření u různých zubů v oblastech hrbolkové skloviny a kořenového dentinu, kde nelze aplikovat výpočet na základě počtu dlouhodobých inkrementálních liniî a jejich periodicity, byla minimální hodnota odhadu stanovena na 6,4 let a maximální na 7 let.

\section{Diskuse: možnosti a limity, výhody, nevýhody a perspektivy}

Metodické přístupy studia mikrostruktury tvrdých zubních tkání je možno v závislosti na výběru použitých inkrementálních markerů rozdělit do dvou hlavních kategorií - méně přesné přístupy využívající povrchovou manifestaci Retziusových linií (perikymata) s nevyhnutelným odhadem dalších parametrů (např. King - Humphrey - Hillson 2005; King - Hillson - Humphrey 2002; Guatelli-Steinberg - Larsen - 


\begin{tabular}{|c|c|c|c|c|c|c|c|c|c|c|c|c|c|c|c|c|c|c|c|c|c|c|c|c|c|c|c|c|c|c|}
\hline $\begin{array}{l}\bar{\xi} \\
\hat{f}\end{array}$ & & & & & & & & & & & & & & & & & & & & & & & & & $\underset{m}{\infty}$ & in & 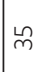 & N & $\stackrel{\circ}{1}$ & \% \\
\hline $\begin{array}{l}\hat{E} \\
\text { f }\end{array}$ & & & & & & & & & & & & & & & & & & & & & & 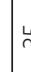 & & $\lesssim$ & $\stackrel{m}{m}$ & in & 訳 & in & $\frac{7}{n}$ & ₹ \\
\hline $\begin{array}{l}\text { च0 } \\
\text { సे }\end{array}$ & & & & & & & & & & & & & & & & & & & & & & & & & $\stackrel{+}{m}$ & $\stackrel{g}{q}$ & 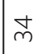 & in & $\stackrel{M}{N}$ & 우 \\
\hline $\begin{array}{l}\text { Eิ } \\
\text { స }\end{array}$ & & & & & & & & & & & & & & & & & & & & & & $\lambda$ & & প্ & $\stackrel{\circ}{m}$ & กิ & $\stackrel{m}{m}$ & in & io & $\stackrel{m}{q}$ \\
\hline $\begin{array}{l}\text { Oे } \\
\varepsilon \\
\text { N }\end{array}$ & & & $\infty$ & व & D & F & $\stackrel{\sim}{\sim}$ & $\infty$ & 3 & $\stackrel{L}{\infty}$ & & & f & & & & & & & & & & & & & & & & & \\
\hline $\begin{array}{l}\text { है } \\
\text { N }\end{array}$ & & & $\curvearrowright$ & $\propto$ & D & $\bar{\gamma}$ & $\stackrel{ \pm}{\sim}$ & 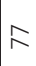 & $\widetilde{\sigma}$ & $\infty$ & & & $\stackrel{\infty}{+}$ & & & & & & & & & & & & & & & & & \\
\hline$\stackrel{m}{m}$ & & & $\stackrel{\infty}{\sim}$ & 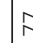 & K & 아 & $\approx$ & 웅 & $\stackrel{\infty}{\infty}$ & $\stackrel{\infty}{\infty}$ & & $n$ & Бn & $\mid \begin{array}{l}\infty \\
\infty \\
\infty\end{array}$ & 字 & $\infty$ & $\stackrel{a}{m}$ & $\pi$ & 守 & $\stackrel{+}{\sim}$ & $\bar{m}$ & ? & & $\bar{m}$ & $\stackrel{m}{m}$ & $g$ & $m$ & 오 & $\begin{array}{l}\infty \\
0 \\
0\end{array}$ & $\stackrel{a}{m}$ \\
\hline$\simeq$ & & & & & & & & & & $\stackrel{m}{\infty}$ & & 6 & g & $q$ & 守 & $m$ & $\stackrel{m}{m}$ & $a$ & 은 & $\bar{\sim}$ & m & ชิ & & $\stackrel{\infty}{\sim}$ & $\underset{m}{\infty}$ & f & $\underset{m}{\infty}$ & $\underset{+}{+}$ & $\hat{\sigma}$ & $\mathscr{q}$ \\
\hline$=$ & & & ‡ & ? & N & $\underset{f}{\forall}$ & $\approx$ & 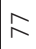 & $\stackrel{\infty}{\infty}$ & $\propto$ & & 6 & g & $\infty$ & in & $\stackrel{\infty}{m}$ & $\stackrel{\circ}{m}$ & ₹ & กี & $\approx$ & $\stackrel{2}{\sim}$ & ra & & 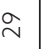 & $m$ & \& & $\underset{m}{\infty}$ & in & $\approx$ & $\stackrel{\mathscr{q}}{+}$ \\
\hline $\begin{array}{l}\bar{E} \\
\stackrel{N}{N}\end{array}$ & & $\stackrel{\stackrel{\sim}{N}}{N}$ & & & & & & & & & & & & & & & & & & & & & & & & & & & & \\
\hline 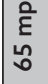 & & $\stackrel{\stackrel{+}{d}}{\sim}$ & $\stackrel{\curvearrowright}{r}$ & $\stackrel{5}{\circ}$ & n & & & & & & & & & & & & & & & & & & & & & & & & & \\
\hline $\begin{array}{l}\hat{E} \\
\text { นึ }\end{array}$ & & 옥 & & & & & & & & & & & & & & & & & & & & & & & & & & & & \\
\hline 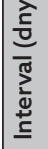 & & $\stackrel{\check{n}}{N}$ & $\infty$ & i & E & $\stackrel{\sim}{f}$ & $\stackrel{ \pm}{\sim}$ & 10 & 8 & $\bowtie$ & & 0 & q & 8 & $\stackrel{g}{q}$ & m & $\hat{m}$ & P & 욘 & $\approx$ & $\stackrel{一}{\text { m }}$ & c & & $\stackrel{\sim}{\sim}$ & $\stackrel{m}{m}$ & g & $\stackrel{\stackrel{n}{m}}{n}$ & i & 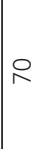 & F \\
\hline 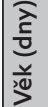 & 0 & $\stackrel{\check{n}}{\sim}$ & $\stackrel{\sim}{m}$ & 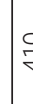 & & 華 & $\stackrel{n}{\sim}$ & 只 & $\frac{0}{\pi}$ & 0 & & $\begin{array}{l}f \\
0\end{array}$ & $\stackrel{\sim}{\infty}$ & న్ & $\bar{n}$ & $\begin{array}{l}\infty \\
\infty \\
o\end{array}$ & 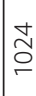 & ஓ & 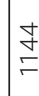 & 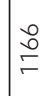 & $\frac{0}{2}$ & તૂ & No & 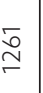 & 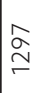 & $\stackrel{\stackrel{\sim}{f}}{m}$ & $\begin{array}{l}\stackrel{\otimes}{0} \\
\stackrel{m}{r}\end{array}$ & $\stackrel{\bar{m}}{\leftarrow}$ & 홍 & 㝍 \\
\hline 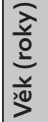 & $\begin{array}{l}8 \\
0 \\
0\end{array}$ & $\begin{array}{l}a \\
o \\
o\end{array}$ & 文 & 7 & $=$ & $\stackrel{\underset{\sim}{\sim}}{=}$ & $\stackrel{\stackrel{\rho}{m}}{r}$ & $\stackrel{i n g}{r}$ & $\stackrel{0}{0}$ & ¿ & & s & $\underset{\sim}{\stackrel{N}{N}}$ & $\mid \begin{array}{c}\text { J } \\
\text { 年 }\end{array}$ & $\begin{array}{l}\bar{\sigma} \\
\sim \\
\end{array}$ & $\stackrel{i}{\sim}$ & $\begin{array}{l}\bar{\infty} \\
\sim \\
\sim\end{array}$ & O & $\stackrel{m}{m}$ & $\frac{\sigma}{m}$ & $\stackrel{\infty}{\stackrel{\infty}{m}}$ & d) & & $\begin{array}{l}\frac{n}{f} \\
m \\
m\end{array}$ & $\stackrel{\stackrel{\leftrightarrow}{\stackrel{\leftrightarrow}{\rho}}}{m}$ & $\begin{array}{l}\infty \\
0 \\
0 \\
m\end{array}$ & $\begin{array}{l}\infty \\
\stackrel{\infty}{m}\end{array}$ & $\frac{\alpha}{\alpha}{ }_{m}$ & $\underset{f}{F}$ & $\underset{\underset{\sim}{\sim}}{\stackrel{\mathscr{P}}{\sim}}$ \\
\hline$\vec{\alpha}$ & & & & & & & & $F$ & $a$ & 7 & & $P$ & $\wedge$ & $\stackrel{m}{r}$ & $\lambda$ & in & in & $\stackrel{?}{-}$ & r & $m$ & $\nabla$ & L & n & t & in & $\wedge$ & in & $\wedge$ & $\stackrel{\circ}{\circ}$ & 0 \\
\hline 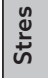 & \begin{tabular}{|l} 
\\
0 \\
0 \\
0 \\
0
\end{tabular} & $\bar{n}$ & ஸึ & r & h & 㐫 & $\circlearrowleft$ & is & in & $a$ & & in & $\frac{0}{n}$ & $\bar{n}$ & $\frac{N}{n}$ & $\frac{m}{n}$ & $\bar{n}$ & $\frac{n}{n}$ & $\frac{i}{n}$ & $\bar{n}$ & $\frac{\infty}{n}$ & 7 & $\frac{5}{n}$ & ్ָ & $\underset{\sim}{\sim}$ & $\underset{\sim}{\sim}$ & 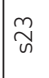 & $\underset{\sim}{\sim}$ & $\underset{\sim}{\sim}$ & ్ָ \\
\hline
\end{tabular}




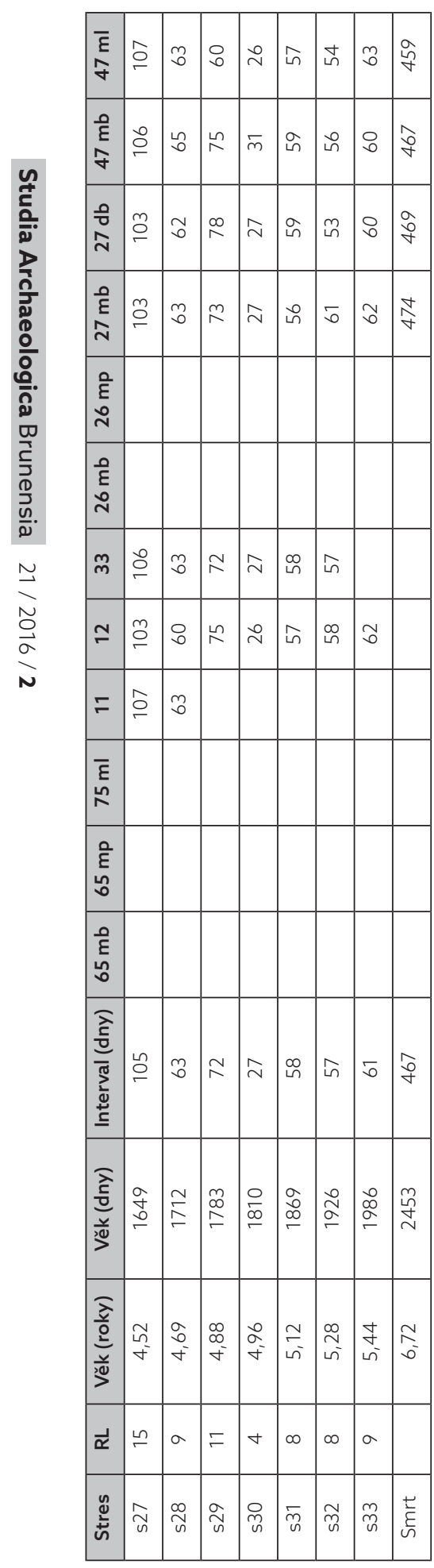

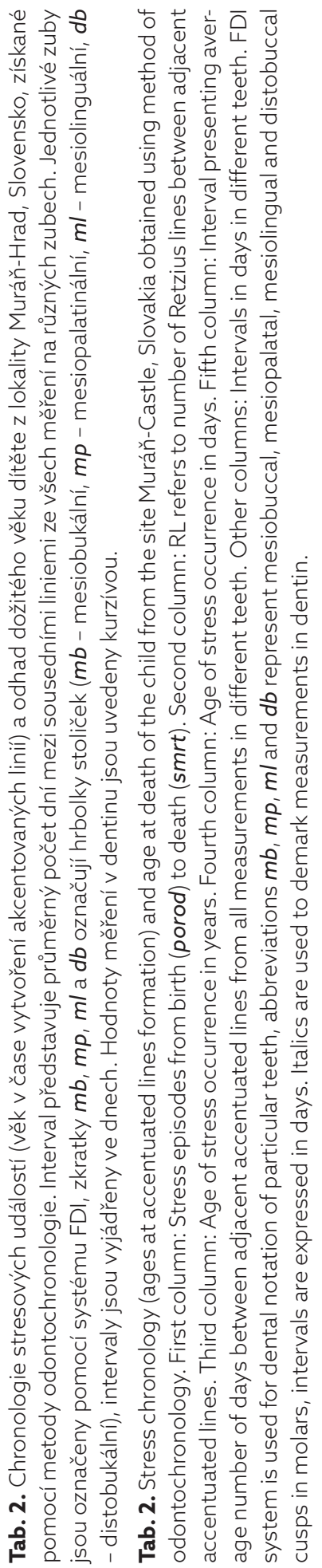


Hutchinson 2004); a přesnější přístupy, vycházející z přímého hodnocení vnitřních markerů (např. FitzGerald et al. 2006; Thomas 2003; Mahoney 2011, 2012; Birch - Dean 2014), které však vyžadují přípravu histologického preparátu a tudíž destrukci zubu. Díky rozvíjejícímu se oboru virtuální histologie je v poslední době možná i nedestruktivní analýza mikrostruktury zubů v 3D zobrazení pomocí rentgenové mikrotomografie $(\mu \mathrm{CT})$ se synchrotronem jakožto zdrojem rentgenového záření a s využitím fázového kontrastu (Smith - Tafforeau 2008). Kvůli vysoké finanční náročnosti se však hodí spíše na zpracování unikátních fosilních nálezů než na rutinní zpracování většího množství vzorků z celých pohřebište, které je nezbytné hodnotit v bioarcheologii při vytváření obecnějších populačních trendů a srovnání. V současnosti tak nejdostupnější přístup přinášející největší množství dat $\mathrm{s}$ nejmenším množstvím odhadovaných parametrů představuje přímé studium histologických výbrusů zubů.

Metoda odontochronologie, založená na histologických analýzách zubní skloviny a dentinu a interpretaci jejich vnitřních inkrementálních struktur (FitzGerald - Rose 2008; Schwartz Dean 2008; FitzGerald - Hillson 2009; Antoine - Hillson - Dean 2009; Dean 2010; Hillson 2014), umožňuje rekonstruovat endogenní záznam vývoje zubů a rané fáze ontogeneze jedince a získat individuálně specifickou chronologii dentálního vývoje a prožitého stresu. Poskytuje odhady chronologického věku (obrázek 5) jedince v určité fázi vývoje, nezávislé na referenční sbírce nebo moderních vývojových standardech. V případě analýz kosterních nálezů v archeologickém kontextu nabízí odontochronologie zejména možnost hodnocení stupně zubního vývoje a prožitého stresu, stresových událostí kolem narození, u nejmladších jedinců důkaz narození a u nedospělých jedinců, kteří zemřeli před dosažením dentální zralosti nezkreslený odhad chronologického věku dožití. ${ }^{7}$
Navíc nám umožňuje srovnání ontogenetických záznamů a vývojových parametrů u jedinců, kteří zemřeli v dětském věku a jedinců, jež se dožili dospělosti, přičemž stejný přístup studia období narození, dětství a dospívaní lze aplikovat nejen u jedinců z populací lidí již (dávno) zemřelých, ale i recentních, žijících lidí (s dokumentovanou životní historií).

Hodnocení stresu, tj. narušení fyziologického vývoje $\mathrm{v}$ důsledku nepříznivých životních podmínek (Larsen 2002), je klíčovým pojmem při studiu zdravotního stavu a životních podmínek minulých populací. Stresové faktory působí na jedince v průběhu celého života, hlavní dopad na výsledný fenotyp a kvalitu života však mají především zátěžové události překonané v průběhu prenatálního a postnatálního období vývoje a růstu (Humphrey - King 2000). Kostní a zubní tkáně v průběhu ontogeneze kosterní soustavy citlivě reagují na negativní změny podmínek zpomalením nebo úplným zastavením růstu a změnami své struktury, tvaru a velikosti. Biologická odezva organizmu na vývojový stres tak může zanechat stopy, které jsou pozorovatelné na kostech a zubech skeletů nacházených v archeologických situacích. Jako indikátory vývojového stresu na zubech se používají např. zpomalený zubní vývoj, redukovaná velikost zubů, zvýšená míra odontometrické fluktuační asymetrie, přítomnost hypoplastických defektů skloviny a mikroskopické defekty tvrdých zubních tkání (Larsen 2002; Humphrey King 2000; Goodman - Rose 1990). Použití odontologických stresových markerů má oproti indikátorům na kostře několik výhod. Kromě lepší zachovalosti zubů v archeologických nálezech je to pozorovatelnost známek stresu i dlouhý čas po působení zátěžových faktorů v důsledku neměnnosti zubů po ukončení vývoje. Kostní tkáň je v průběhu života neustále remodelována, zatímco sklovina se po vytvoření nemění a změny v dentinu jsou minimální, takže k modifikaci dochází jen vlivem externích faktorů 
(atrice, abraze, nemoci, léčebné zásahy). Především je to však jedinečný cirkadiánní záznam v mikrostruktuře tvrdých zubních tkání umožňující přesnou rekonstrukci chronologie vývoje a stresových událostí pomocí histologických analýz. Ve srovnání s běžně používanými metodami makroskopického hodnocení sklovinných hypoplázií (někdy jen na úrovni př́itomnost/ nepřítomnost) umožňuje odontochronologie i identifikaci jemných růstových narušení skloviny, která se neprojeví výraznou změnou na povrchu zubu, a jejich přesnější chronologické zařazení nezávislé na referenčním souboru. Také dovoluje spolehlivější identifikaci systematických stresových epizod díky identifikaci stejných defektů u různých zubních typů, a to i v té části skloviny, která je ukrytá uvnitř korunky. $\mathrm{Z}$ důvodu odlišných projevů růstových narušení na zubech různého typu jsou pro studium hypoplastických změn často doporučovány a vybírány přední zuby nebo jen některý z nich (Goodman - Rose 1990). V takových případech však může dojít k nezaznamenání na povrchu zubu méně výrazných, a také dříve nebo později překonaných stresových událostí. Vysoká frekvence stresových linií viditelných na histologických výbrusech zubů zjištěná i u jedince $\mathrm{v}$ zde prezentované př́ípadové studii také ukazuje, že hypoplastické defekty pozorovatelné na povrchu zubních korunek představují jen nejviditelnější část širokého spektra prožitých stresových událostí, navíc s obtížně definovatelným počátkem a koncem (časovým zařazením). Jak již bylo řečeno výše, u archeologických kosterních nálezů nelze přícinu vzniku stresových linií kromě neonatální linie blíže určit, to však platí i pro hodnocení hypoplastických defektů. ${ }^{8}$ Při aplikaci metody odontochronologie u většího počtu jedinců z populace se nabízí možnost kvantitativního statistického srovnání celých sekvencí stresových linií (hustota, síla, frekvence, gradienty atd.) pomocí statistických metod a jejich statistická konfrontace např. s dalšími indikáto- ry stresu na kostře, dožitým věkem nebo mortalitou třeba při výzkumu vlivu stresu prožitého v rané fázi ontogeneze na život jedince v dospělosti (Humphrey - King 2000; Thomas 2003).

Správný, přesný a spolehlivý odhad dožitého věku z kosterních pozůstatků nedospělých či dospělých jedinců neznámého původu je klíčovým úkolem v různých oblastech antropologie (Black - Ferguson 2011; Hillson 2014; Katzenberg - Saunders 2008), avšak mnohdy velice problematickým. Zejména v př́padě odhadu dožitého věku jedinců z minulých populací, jelikož téměř všechny běžně používané metody (White - Black - Folkens 2011; Dobisiková 1999) pro odhad věku využívají referenční sbírky a standardy vycházející z údajů platných pro moderní populace, většinou pohlavně a populačně závislé.

$\mathrm{V}$ bioarcheologii, ale i forenzních vědách se nejčastěji k odhadu věku dožití nedospělých jedinců využívají poměrně rychlé a neinvazivní metody, založené na hodnocení postupu mineralizace a erupce zubů. Tyto tradiční metody a jejich deriváty (např. Schour - Massler 1941; Moorrees - Fanning - Hunt 1963a,b; Demirjian - Goldstein - Tanner 1973; Ubelaker 1999; AlQahtani - Hector - Liversidge 2010) srovnávají rentgenové snímky zubů hodnoceného jedince s vytvořenými schématy ze zubních atlasů a klasifikují jedince do určitého stádia vývoje. Často však dochází k situaci, podobně jako u zde hodnoceného jedince, že některé zuby spadají do více schémat. Dalším problémem je projekce při vytváření rentgenového snímku, kdy by v ideálním případě měly být zuby snímkovány z profilu, což je u kosterních pozůstatků (se zuby v oblouku čelisti) náročné docílit. Ve výsledku tak může být zubní věk nesprávně určen i kvůli špatné poloze zubu při snímkování. Kromě toho jde o odhad biologického věku, vztahujícího se ke stupni vývoje chrupu dosaženého v čase smrti, který neumožňuje říct, jaký byl chronologický věk jedince v čase dosažení tohoto stupně biologického vývoje. Stupeň 


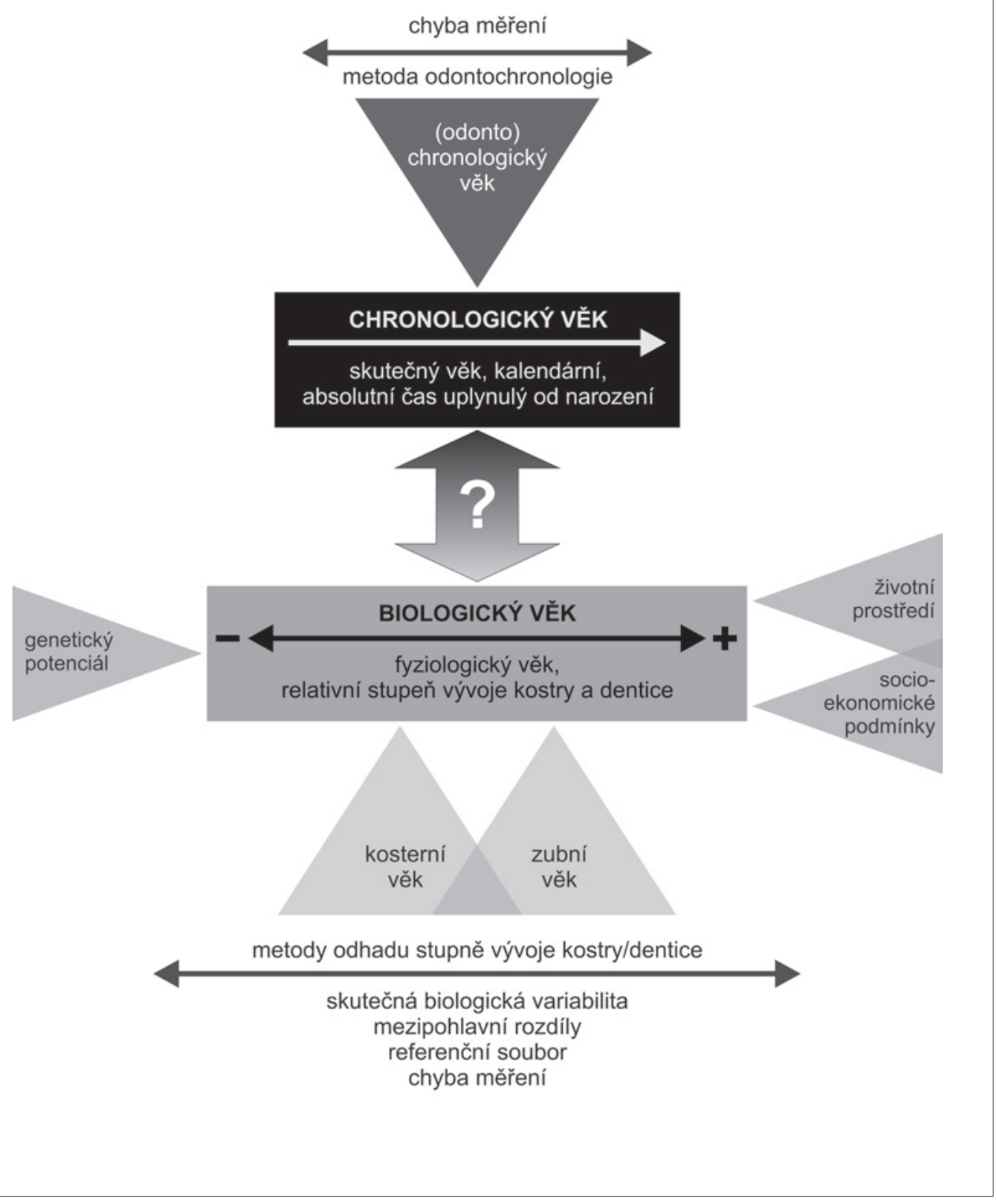


\ Obr. 5. Schéma hodnocení dožitého věku z kosterních pozůstatků nedospělých jedinců. Chronologický věk udává skutečný, kalendáňní věk, absolutní čas uplynulý od narození. Biologický věk nedospělého jedince představuje výraz postupu individuálního fyziologického vývoje organizmu z hlediska maturace a růstu kostry a zubů, který je ovlivněn genetickým potenciálem jedince, jeho životním prostředím a socio-ekonomickými podmínkami. Znaménko mínus a plus u biologického věku indikuje zpomalení nebo zrychlení vývoje vzhledem k chronologickému věku na základě vybraných vývojových standardů. U kosterních pozůstatků člověka může být chronologický věk určen pomocí metody odontochronologie jako (odonto)chronologický věk, kde jediným zdrojem variance $v$ odhadech je chyba měření. $V$ bioarcheologii/kosterní antropologii může být biologický věk vyjádřen jako kosterní věk nebo zubní věk, který Ize odhadnout pomocí různých metod stanovujících stupeň vývoje kostry nebo dentice, dosažený v čase smrti. Avšak téměř všechny běžně používané metody pro odhad věku využívají referenční sbírky a standardy vyvinuté na základě dat z moderních populací, většinou pohlavně a populačně závislé. Výsledný odhad věku pak představuje neoddělitelnou kombinaci přirozené biologické variability, mezipohlavních rozdílů v růstových vzorcích, zkreslení v důsledku výběru referenčního souboru použité metody a $v$ neposledním řadě chyby měření. Odhady biologického věku stanovené různými metodami se tak mohou v různé míre rozcházet nejen s věkem chronologickým, ale i mezi sebou. Použití takto stanoveného biologického věku jako ukazatele (zástupný údaj) chronologického věku je pak nejen zatíženo chybou, ale zároveň vede ke ztrátě značného množství informace, které nabízí až znalost rozdílu chronologického a biologického věku jedince. Při hodnocení životních podmínek minulých populací má totiž největší výpovědní hodnotu o populaci právě jejich vzájemný vztah.

4 Fig. 5. Schematic of age at death estimation from skeletal remains of subadults. Chronological age (chronologický věk) refers to the real, calendar age, absolute time passed since birth (skutečný věk, kalendární, absolutní čas uplynulý od narození). Biological age of subadults (biologický věk) refers to the individual physiological state of organism in terms of the skeletal and dental development (fyziologický věk, relativní stupeň vývoje kostry a dentice), influenced by individual genetic potential (genetický potenciál), living environment (životní prostředi) and socio-economic conditions (socio-ekonomické podmínky). Minus sign and plus sign indicate retarded and accelerated development (biological age) relate to the chronological age based on some chosen developmental standards. In case of human skeletal remains, chronological age can be estimated using the method of odontochronology (metoda odontochronologie) as (odonto)chronological age ((odonto)chronologický věk) where the only source of variation in estimates is the measurement error (chyba měření). In bioarchaeology/physical anthropology, biological age can be estimated as skeletal age (kosterní věk) or dental age (zubni věk) using different methods of age estimation referring to the stage of skeletal or dental development (metody odhadu stupně vývoje kostry/dentice) reached at death. However, to estimate age of individuals from past populations, almost all of the normally applied methods rely on reference collections and use growth and aging standards developed from present-day populations, mostly sex- and population-dependent. The estimated age thus contains some unknown mix of natural biological variability (skutečná biologická variabilita), between-sex differences in growth patterns (mezipohlavní rozdily), bias due to choice of reference sample of applied method (referenční soubor) and not least the measurement error (chyba měření). Estimates of biological age obtained using different methods may thus diverge in varying degrees not only with chronological age, but also among themselves. Use of these estimates of biological age as an indicator (representative) of chronological age is then not only a source of bias and error, but it also leads to the significant loss of information that offers only the knowledge of the difference between chronological and biological age of an individual. When assessing the living conditions of past populations, the greatest informative value about the population provides entirely their relationship. 
vývoje dentice, tj. zubní věk ve vztahu k chronologickému věku je přitom důležitým aspektem hodnocení charakteru vývoje a průběhu růstových procesů (obrázek 5). Ve srovnání s konvenčním radiologickým př́ístupem (rentgenologické vyšetření, počítačová tomografie) je sice histologický př́stup studia růstových procesů v zubech destruktivní, časově, technicky a analyticky náročnější a tak i limitovaný na soubory o menším počtu př́ípadů nebo případové studie, získaná data však lze pokládat za obsáhlejší a přesnější (Beynon et al. 1998; Smith 2008; Antoine - Hillson - Dean 2009). Pomocí metody odontochronologie lze hodnotit časování vývojových stádií zubů nejen s přesností na roky a měsíce, ale až s přesností na týdny a dny. Za určitých okolností je možné i jejich chronologické zařazení, tj. lze zjistit, v jakém věku začal růst jednotlivých zubů, jakou rychlostí probíhalo formování korunky a kořene, kdy byly zuby plně vytvořeny a jaké mezi nimi byly vzájemné vývojové vztahy (pořadí). To vše lze hodnotit $\mathrm{u}$ každého jednotlivce a není $\mathrm{k}$ tomu potřeba referenční populace. Výsledek tedy neovlivňují populační (variabilita vnitro- a mezi-populační) ani pohlavní rozdíly (podobně jako $\mathrm{v}$ případě jiných aspektů vývoje probíhá vývoj zubů u dívek v předstihu před chlapci, přičemž pohlaví u nedospělých většinou neznáme (Hillson 1996; Hillson 2014)).

Odhad věku nedospělých jedinců pomocí odontochronologie není založen na žádné referenční populaci, je zcela nezávislý od referenčních standardo̊, jelikož zubní inkrementy se kvantifikují přímo u každého jedince. Nepotřebujeme referenční populaci a model růstu lidí v této populaci, abychom podle vývoje zubů hodnoceného případu a modelu referenční populace odvodili dožitý věk hodnoceného případu. Oproti tradičním metodám tedy nejde o statistický odhad na úrovni populace, ale prostý součet denních př́růstků na úrovni jedince. Teoreticky potřebujeme jen detailně zobrazit celý časový záznam v zubech a všechny dny jeden po druhém prostě spočítat. Protože je to ale v praxi zdlouhavé a některé části záznamu nemusí být dobře zobrazeny, resp. mohou být tafonomicky poškozeny a nečitelné, pomáháme si lokálně odhadem počtu dní na základě měření vzdálenosti podle dobře viditelných oblastí (Dean 1998; Reid - Beynon - Rozzi 1998; Birch Dean 2014; Hillson 2014; Dirks et al. 2010; Dirks - Bromage - Agenbroad 2012). Metodu tedy lze aplikovat i u jedinců, pro které není k dispozici (neznámé forenzní případy) nebo dokonce ani nemůže existovat (archeologické nálezy) referenční vzorek dokumentovaných případů. Při aplikaci této metodiky na úrovni populace se pak nabízí možnost srovnání nezávislého odhadu (odonto)chronologického věku s biologickým věkem podle vývoje kostry nebo dentice. Ve vztahu k ukazatelům stresu by pak mohl být sledován normální vývoj a hodnocena retardace růstu v důsledku zhoršených životních podmínek bez ohledu na moderní vývojové standardy. Také je otázka, jak by si z hlediska vnitropopulační a mezipopulační variability odpovídaly růstové vzorce a dosažený stupeň kosterního a dentálního vývoje mezi pohlavími, jelikož jak vývoj kostry (Scheuer - Black 2004), tak i dentice (Hillson 1996; Hillson 2014) je u dívek v předstihu před chlapci. Se znalostí pohlaví jedince získaného pomocí molekulárně-genetických metod by zjištěné rozdíly mohly pomoci při vývoji nových metod odhadu pohlaví u nedospělých jedinců.

Hlavní nevýhodou odontochronologie je její invazivnost, při přípravě výbrusů totiž dochází k částečné destrukci zubu (zůstává část zubu zalitá v pryskyřici a histologický preparát). Je potřeba si však uvědomit, že se analyzuje jen několik zubů - v závislosti od stavu nálezu a výzkumné otázky může stačit třeba jen jeden dočasný zub u nejmenších dětí a čtyři trvalé zuby pokrývající období vývoje celé dentice u dospělých jedinců (např. špičák a všechny tři stolič- 
ky). U nejvzácnějších nálezů lze aplikovat výše zmíněnou virtuální histologii. Zuby jsou navíc předem detailně dokumentovány fotograficky, radiologicky, vytváří se jejich fyzické či virtuální repliky, takže jejich morfologie se pro budoucí výzkum neztrácí. Při multidisciplinárním přístupu a pečlivém a promyšleném plánování odběrů vzorků lze materiál jednoho zubu využít kromě histologických analýz např́klad k analýze stopových prvků (LA-ICP-MS), diagenetické analýze či analýze izotopů (Dolphin et al. 2016). Podle našeho názoru navzdory její invazivnosti převyšují zisky metody odontochronologie nad náklady ve formě ztráty několika zubů. Př́stup k nakládání s archeologickými nálezy je vždy odborný konsensus ohledně kompromisu mezi jejich fyzickým zachováním (resp. zachováním jejich reliktů) a analýzou. Jestli větší hodnotu má nález samotný (de facto „věc“) nebo informace v něm obsažené. Současný trend jistě silně směřuje k neinvazivnosti výzkumných procedur. Stejně tak ale postupuje směrem k virtualizaci a elektronizaci dat, mimo jiné i proto, že získaná data (čísla, záznamy) rozšířená v mnoha kopiích a uložená na mnoha místech mají menší riziko úplné ztráty či destrukce. Je minimálně věcí diskuse, jestli pro zachování nálezu (zde kompletní informace o zubech, získané v jejich nejlepším možném stavu těsně po vyzvednutí ze země) uděláme více odbornou analýzou jejich detailní mikrostruktury, makroskopickým záznamem trojrozměrného tvaru a radiologickým záznamem vnitřní struktury, byt za cenu fyzické ztráty několika zubů, nebo jejich prostým uložením do depozitáře, ponechávajíc je vlivu vzdušného kyslíku, vlhkosti a mikroorganismů, poryvům budoucích společenských změn či zapomnění.

Nutno však říct, že i v prrípadě histologických analýz mohou být výsledky negativně ovlivněny například kvalitou zhotovených výbrusů, šikmou orientací řezu, výběrem konkrétní metodiky určování délky formování příslušné části zubu (Dean 1998; Smith - Reid - Sirianni 2006; Hillson 2014) nebo nečitelností záznamu v důsledku změny tkáně vlivem postdepozičních/ tafonomických procesů. Podstatné však je, že teoretická východiska a základy této metody jsou ve srovnání s východisky jiných metod nesrovnatelně pevnější, jelikož metoda je zcela nezávislá na pohlaví a populační př́ślušnosti jedince a výsledky tudíž absolutně individualizované, navíc komplexnější (ne jenom zubní vývoj, ne jenom stres, ne jenom dožitý věk,...). Časová náročnost i potřeba technického a personálního zázemí je pak přijatelná ve srovnání s úsilím vynaloženým na tvorbu různých metod s rozličnými východisky a předpoklady aplikace nebo na testování tradičních metod, revidování standardů a vývoj jejich populačně, pohlavně či věkově specifických modifikací. Často pak dochází $\mathrm{k}$ vytváření průměrů $\mathrm{z}$ průměrů, rozdílné vhodnosti aplikace metody pro různé věkové kategorie, diskutabilnímu statistickému srovnávání výsledků různých studií. Významné rozdíly ve vývoji dentice přitom byly zjištěny dokonce u jednovaječných dvojčat (Pechniková et al. 2014). Vývoj zubů neprobihá v přesném načasování čistě pod genetickou kontrolou bez vlivu prostředí. Populační, environmentální vlivy tak znemožňují existenci nějaké univerzální populačně nezávislé metody referenčního typu a odhadů na základě průměrů, protože když se můžou takto významně lišit dva geneticky úplně stejní lidé v rámci jedné populace, jak se pak liší vlivem prostředí a genů nepříbuzní lidé téže populace a jak lidé z úplně jiných populací? Při studiu kosterních pozůstatků z archeologických nalezišt nikdy nebudeme mít jistotu, že se dopátráme skutečně toho, jací tito lidé byli, v jakých životních podmínkách žili a jaké události museli v průběhu svého života překonat. Můžeme se však pokusit získat maximální množství detailních, co nejpřesnějších a nejspolehlivějších informací o nich samotných upřednostněním pracnější analýzy individuálních př́ípadů 
před jednodušším a rychlejším hodnocením velkých souborů pomocí referenčních metod, jejichž validita bude vždy nejistá v důsledku neřešitelných nejistot v samém jejich principu.

\section{Závěr}

Inkrementální způsob růstu s jedinečným cirkadiánním záznamem $\mathrm{v}$ mikrostruktuře tvrdých zubních tkání a schopnost zubů zaznamenávat metabolické změny v průběhu jejich vývoje a uchovat tento záznam po celou dobu existence zubu jsou základními východisky metody odontochronologie, jež umožňuje rekonstruovat podstatnou část ontogeneze a životní historie jedince pomocí histologické analýzy výbrusů zubo̊. Díky této metodě lze získat detailní chronologii zubního vývoje nezávislou na referenčních sbírkách a moderních vývojových standardech a u nedospělých jedinců s neukončeným vývojem chrupu v čase smrti zároveň odhad dožitého věku. Mnohem komplexněji a přesněji také lze hodnotit působení vývojového stresu a rekonstruovat chronologii stresových událostí. Navzdory relativně dlouhé době od prvního použití histologické analýzy zubů pro odhad věku z kosterních pozůstatků však zatím tato metoda v bioarcheologii při hodnocení celých populací své širší uplatnění nenašla. I když jde o částečně destruktivní metodu, finančně, technicky i časově náročnější, ve srovnání s radiologickým vyšetřením nebo externím hodnocením povrchu zubů má zařazení histologického prrístupu a analýza zubních výbrusů v bioarcheologických studiích minulých populací potenciál přinést detailnější informace o průběhu vývoje jedince a komplexnější obraz o životě lidí v minulosti.

\section{Poděkování}

Děkujeme Dr. Wendy Dirks za její ochotu, odborné rady a možnost navštivit School of Dental Sciences, Newcastle University, UK, za účelem individuálního školení první autorky v analýze mikrostruktury tvrdých zubních tkání. Rovněž děkujeme Pam Walton za poskytnutí protokolů a rady ohledně prípravy výbrusů. Náš velký dík patří také Petrovi Zaunstöckovi za technickou podporu a prípravu výbrusů.

Děkujeme dvěma anonymním recenzentům za cenné komentáře k první verzi př́spěvku.

1) U člověka 6 až 12 dní, nejčastěji však 8 nebo 9 dní (Smith - Martin - Leakey 2003; Reid - Ferrell 2006; Reid Dean 2006).

2) Pro označování jednotlivých zubů a jejich polohy v chrupu existuje několik různých způsobů. Na zasedání Mezinárodni federace zubních lékařu (Fédération Dentaire Internationale) v roce 1972 byl přijat a doporučen k všeobecnému používaní dvojčíselný FDI systém značení, kdy je každý zub označen dvojčíselným symbolem vyjadřujícím, ze kterého kvadrantu kterého chrupu zub pochází (první číslo 1-4 pro trvalý chrup, 5-8 pro dočasný v pořadí pravý horní, levý horní, levý dolní, pravý dolní) a na jaké pozici od střední čáry se nachází (1-8 pro trvalý chrup, 1-5 pro dočasný).

3) Postupné měření podél dentino-sklovinné hranice umožňuje i hodnocení částečně abradovaných zubů.

4) Jelikož všechny hodnoty z prvního a druhého měření spadaly do rozmezí hodnot zjištěných u dalších zubů, uvádíme ve výsledcích pouze průměrnou hodnotou. Výsledné minimální a maximální naměřené hodnoty intervalu u všech zubů lze vyčíst v tabulce 2.

5) Demirjianova metoda (Demirjian - Goldstein - Tanner 1973) předpokládá přítomnost všech zubů levého dolního kvadrantu vyjma třetí stoličky a nebyla použita z důvodu chybějících dolních řezáků

6) Tato metoda však není založena na dokumentovaném souboru se známým věkem, ale na odhadech věku pomocí Ubelakerovho schématu (Dobisiková 1999)

7) Cementochronologie neboli metoda odhadu chronologického věku na základě analýzy inkrementů zubního cementu vychází z jiného principu - využívá apozice kořenového cementu a je založena na počítání ročních 
př́růstků, podobně jako počítání letokruhů v dendrochronologii. K získanému počtu let se však musí ještě připočíst věk jedince v čase erupce zubu, jenž však již není individuálně specifický, ale průměrný/referenční (Bertrand et al. 2014; Wedel - Wescott 2015; Alghonamy - Gaballah - Labah 2015).

8) O spojení konkrétní události s markery stresu v mikrostruktuře zubů jsme se pokusili u kosterních pozůstatků juvenilního jedince z mladohradištního pohřebiště Dětkovice - „Za zahradama“, okres Prostějov, který přežil vážnou stresovou událost, o níž svědčí zhojená fraktura proximálního konce pravé kosti stehenní (Hupková et al. 2015; Račanská et al. 2014).

\section{Literatura}

Alghonamy, W. Y. - Gaballah, O. M. - Labah, D. A. 2015: Age estimation in adult human sound and periodontally affected teeth using tooth cementum annulations. Tanta Dental Journal 12, 277-285.

AlQahtani, S. J. - Hector, M. P. - Liversidge, H. M. 2010: Brief communication: The London atlas of human tooth development and eruption. American Journal of Physical Anthropology 142, 481-490.

Antoine, D. - Hillson, S. - Dean, M. C. 2009: The developmental clock of dental enamel: a test for the periodicity of prism cross-striations in modern humans and an evaluation of the most likely sources of error in histological studies of this kind. Journal of Anatomy 214(1), 45-55.

Bertrand, B. - Robbins Schug, G. - Polet, C. - Naji, S. Colard, T. 2014: Age-at-death estimation of pathological individuals: A complementary approach using teeth cementum annulations. International Journal of Paleopathology, v tisku.

Beynon, A. - Clayton, C. - Rozzi, F. - Reid, D. 1998: Radiographic and histological methodologies in estimating the chronology of crown development in modern humans and great apes: a review, with some applications for studies on juvenile hominids. Journal of Human Evolution 35(4-5), 351-370.

Birch, W. - Dean, M. C. 2014: A method of calculating human deciduous crown formation times and of estimating the chronological ages of stressful events occurring during deciduous enamel formation. Journal of Forensic and Legale Medicine 22, 127-144.

Black, S. - Ferguson, E. E. 2011: Forensic anthropology: 2000-2010: CRC Press.

Dean, M. C. 1998: A comparative study of cross striation spacings in cuspal enamel and of four methods of estimating the time taken to grow molar cuspal enamel in Pan, Pongo and Homo. Journal of Human Evolution 35(4-5), 449-462.
Dean, M. C. 2000: Incremental markings in enamel and dentine: what they can tell us about the way teeth grow. In: Teaford, M. - Smith, M. - Ferguson, M. (eds.), Development, Function and Evolution of Teeth. Cambridge University Press, 119-130.

Dean, M. C. 2010: Retrieving chronological age from dental remains of early fossil hominins to reconstruct human growth in the past. Philosophical Transactions of the Royal Society B-Biological Sciences 365(1556), 3397-3410.

Dean, M. C. - Beynon, A.D. 1991: Histological reconstruction of crown formation times and initial root-formation times in a modern human child. American Journal of Physical Anthropology 86(2), 215-228.

Dean, M. C. - Elamin, F. 2014: Parturition lines in modern human wisdom tooth roots: do they exist, can they be characterized and are they useful for retrospective determination of age at first reproduction and/or inter-birth intervals? Annals of Human Biology 41(4), 358-367.

Demirjian, A. - Goldstein, H. - Tanner, J. M. 1973: A New System of Dental Age Assessment. Human Biology 45(2), 211-227.

Dirks, W. 1998: Histological reconstruction of dental development and age at death in a juvenile gibbon (Hylobates lar). Journal of Human Evolution 35(4-5), 411-425.

Dirks, W. - Bromage, T. - Agenbroad, L. 2012: The duration and rate of molar plate formation in $\mathrm{Pa}$ laeoloxodon cypriotes and Mammuthus columbi from dental histology. Quaternary International 255, 79-85.

Dirks, W. - Humphrey, L. - Dean, M. C. - Jeffries, T. 2010: The Relationship of Accentuated Lines in Enamel to Weaning Stress in Juvenile Baboons (Papio hamadryas anubis). Folia Primatologica 81(4), 207-223. 
Dirks, W. - Reid, D. - Jolly, C. - Phillips-Conroy, J. - Brett, F. 2002: Out of the mouths of baboons: Stress, life history, and dental development in the Awash National Park hybrid zone, Ethiopia. American Journal of Physical Anthropology 118(3), 239-252.

Dobisiková, M. 1999: Určování věku. In: Stloukal, M. (ed.), Antropologie: př́ručka pro studium kostry. Praha: Národní muzeum, 235-339.

Dolphin, A. E. - Teeter, M. - White, C. D. - Longstaffe, F. 2016: Limiting the impact of destructive analytical techniques through sequential microspatial sampling of the enamel from single teeth. Journal of Archaeological Science Reports 5, 537-541.

FitzGerald, C. - Hillson, S. 2009: Deciduous Tooth Growth in an Ancient Greek Infant Cemetery. In: Koppe, T. - Meyer, G. - Alt, K. W. (eds): Comparative Dental Morphology. Front Oral Biol. 13, 178-183.

FitzGerald, C. - Rose, J. 2008: Reading between the lines: dental development and subadult age assessment using the microstructural growth markers of teeth. In: Katzenberg, M. - Saunders, S. Biological Anthropology of the Human Skeleton, Second Edition. Wiley - Sons, 237-263.

FitzGerald, C. - Saunders, S. 2005: Test of histological methods of determining chronology of accentuated striae in deciduous teeth. American Journal of Physical Anthropology 127(3), 277-290.

FitzGerald, C. - Saunders, S. - Bondioli, L. - Macchiarelli, R. 2006: Health of infants in an Imperial Roman skeletal sample: Perspective from dental microstructure. American Journal of Physical Anthropology 130(2), 179-189.

Goodman, A. - Rose, J. 1990: Assessment of systemic physiological perturbations from dental enamel hypoplasias and associated histological structures. Yearbook of Physical Anthropology 33, 59-110.

Guatelli-Steinberg, D. - Larsen, C. - Hutchinson, D. 2004: Prevalence and the duration of linear enamel hypoplasia: a comparative study of Neandertals and Inuit foragers. Journal of Human Evolution $47(1-2), 65-84$.

Hillson, S. 1996: Dental Anthropology: Cambridge University Press.

Hillson, S. 2014: Tooth Development in Human Evolution and Bioarchaeology: Cambridge University Press.
Humphrey, L. T. - King, T. 2000: Childhood stress: a lifetime legacy. Anthropologie XXXVIII/1, 33-49.

Hupková, A. - Dirks, W. - Králik, M. - Račanská, M. 2015: Retrieval of a developmental record from dental remains: Stress chronology and age at death assessment of a juvenile skeleton from an early medieval site in Moravia, Czech Republic. In: Sázelová, S. - Novák, M. - Mizerová, A. (eds.), Forgotten times and spaces. New perspectives in paleoanthropological, paleoetnological and archeological studies. Brno: Masarykova univerzita - Archeologický ústav AV ČR, 2015:

Katzenberg, M. A. - Saunders, S. 2008: Biological Anthropology of the Human Skeleton, Second Edition. Wiley \& Sons.

King, T. - Hillson, S. - Humphrey, L. 2002: A detailed study of enamel hypoplasia in a post-medieval adolescent of known age and sex. Archives of Oral Biology 47(1), 29-39.

King, T. - Humphrey, L. - Hillson, S. 2005: Linear enamel hypoplasias as indicators of systemic physiological stress: Evidence from two known ageat-death and sex populations from postmedieval London. American Journal of Physical Anthropology 128(3), 547-559.

Larsen, C. S. 2002: Bioarchaeology: The lives and lifestyles of past people. Journal of Archaeological Research 10(2), 119-166.

Lieberman, D. 1993: Life history variables preserved in dental cementum microstructure. Science 261(5125), 1162-1164.

Lieberman, D. 1994: The biological basis for seasonal increments in dental cementum and their application to archaeological research. Journal of Archaeological Science 21, 525-539.

Mahoney, P. 2011: Human Deciduous Mandibular Molar Incremental Enamel Development. American Journal of Physical Anthropology 144(2), 204-214.

Mahoney, P. 2012: Incremental Enamel Development in Modern Human Deciduous Anterior Teeth. American Journal of Physical Anthropology 147, 637-651.

Malček, R. - Šimkovic, M. 2013: Výskumná správa z výskumu č. 82/2013 „Muráň-Hrad, Dom velitela“. Nálezová správa: Archeologický ústav Slovenskej akadémie vied v Nitre. 
Moorrees, C. - Fanning, E. - Hunt, E. 1963a: Age Variation of Formation Stages for Ten Permanent Teeth. Journal of Dental Research 42, 1490-1502.

Moorrees, C. - Fanning, E. - Hunt, E. 1963b: Formation and Resorption of Three Deciduous Teeth in Children. American Journal of Physical Anthropology 21, 205-213.

Naylor, J. - Miller, W. - Stokes, G. - Stott, G. 1985: Cementum annulation enhancement: A technique for age determination in man. American Journal of Physical Anthropology 68, 197-200.

Papageorgopoulou, C. - Suter, S. - Ruhli, F. - Siegmund, F. 2011: Harris Lines Revisited: Prevalence, Comorbidities, and Possible Etiologies. American Journal of Human Biology 23(3), 381-391.

Pechniková, M. - De Angelis, D. - Gibelli, D. - Vecchio, V. - Cameriere, R. - Zeqiri, B. - Cattaneo, C. 2014: Twins and the paradox of dental-age estimations: A caution for researchers and clinicians. HOMO - Journal of Comparative Human Biology 65, 330-337.

Račanská, M. - Hupková, A. - Dirks, W. - Vargová, L. - Králik, M. 2014: A study of the juvenile skeleton from the early medieval site in Moravia, Czech Republic: Attempt to age at injury estimation using stress chronology from developmental record in the microstructure of teeth (preliminary report). In: Morphology 2014:

Reid, D. - Beynon, A. - Rozzi, F. 1998: Histological reconstruction of dental development in four individuals from a medieval site in Picardie, France. Journal of Human Evolution 35(4-5), 463-477.

Reid, D. - Dean, M. C. 2006: Variation in modern human enamel formation times. Journal of Human Evolution 50(3), 329-346.

Reid, D. - Ferrell, R. 2006: The relationship between number of striae of Retzius and their periodicity in imbricational enamel formation. Journal of Human Evolution 50(2), 195-202.

Schaefer, M. - Black, S. - Scheuer, L. 2009: Juvenile Osteology: A Laboratory and Field Manual. London: Elsevier.

Scheuer, L. - Black, S. 2004: The Juvenile Skeleton. London: Academic Press.
Schour, I. - Massler, M. 1941: The development of the human dentition. Journal of the American Dental Association 28, 1153-1160.

Schwartz, G. - Dean, M. C. 2008: Charting the chronology of developing teeth. In: Irish, J. - Nelson, G. (eds.), Technique and Application in Dental Anthropology. Cambridge University Press, 219-233.

Smith, T. 2008: Incremental dental development: Methods and applications in hominoid evolutionary studies. Journal of Human Evolution 54(2), 205-224.

Smith, T. - Martin, L. - Leakey, M. 2003: Enamel thickness, microstructure and development in Afropithecus turkanensis. Journal of Human Evolution 44(3), 283-306.

Smith, T. - Reid, D. - Sirianni, J. 2006: The accuracy of histological assessments of dental development and age at death. Journal of Anatomy 208(1), 125-138.

Smith, T. M. - Tafforeau, P. 2008: New Visions of Dental Tissue Research: Tooth Development, Chemistry, and Structure. Evolutionary Anthropology 17(5), 213-226.

Stloukal, M. - Hanáková, H. 1978: Die Länge der Längsknochen altslawischer Bevölkerungen unter besonderer Berücksichtigung von Waschstumsfragen. Homo 29(1), 53-69.

Thomas, R. F. 2003: Enamel defects, well-being and mortality in a medieval Danish village. Dissertation Thesis. Pennsylvania State University.

Ubelaker, D. H. 1999: Human Skeletal Remains: Excavation, Analysis, Interpretation, Third Edition. Washington, D. C.: Taraxacum.

Wapler, U. - Crubézy, E. - Schultz, M. 2004: Is cribra orbitalia synonymous with anemia? Analysis and interpretation of cranial pathology in Sudan. American Journal of Physical Anthropology 123(4), 333-339.

Wedel, V. L. - Wescott, D.J. 2015: Using dental cementum increment analysis to estimate age and season of death in African Americans from an historical cemetery in Missouri. International Journal of Paleopathology, v tisku.

White, T. D. - Black, M. T. - Folkens, P. A. 2011: Human Osteology, Third Edition. San Diego: Elsevier Academic Press. 


\section{Different lines of our lives: Incremental lines in the microstructure of teeth and their applications in the analysis of human remains}

Throughout the period of development and growth of the teeth, the cells that secrete dental hard tissues leave a record of their activity in the form of growth markers called incremental lines. These features are formed in regularly repeating periodic intervals and correspond to each other in both enamel and dentine. They are often referred to as short-period markers or daily increments representing a 24-hour rhythm and long-period markers representing more than a 24-hour rhythm. The longer periodicity varies between individuals; in humans between 6 and 12 days (Smith - Martin - Leakey 2003; Reid - Ferrell 2006; Reid - Dean 2006), but remains constant in all teeth of one individual dentition. Daily increments are known as cross striations in enamel and as von Ebner's lines in dentine; the long-period increments as striae of Retzius or Retzius lines in enamel and Andresen lines in dentine (Dean 2000; Smith 2008; Smith - Tafforeau 2008; FitzGerald - Rose 2008; Hillson 2014).

Besides these regular time markers, metabolic and physiological disturbances caused by stressful events are also recorded in the microstructure of teeth, as ameloblasts and odontoblasts are very sensitive to physiological upsets (Dean - Elamin 2014). This record is visible in histological sections of teeth as $a c$ centuated lines or stress lines in both the enamel and dentine (Dean 2000; Smith 2008; Smith - Tafforeau 2008; FitzGerald - Rose 2008; Hillson 2014). As metabolic and physiological disturbances occur at a particular point in development, they are recorded in the microstructure of all the teeth that are forming at the time of the stress event. Accentuated lines can thus be used as registration marks and cross-matched between teeth. As teeth develop in an overlapping sequence, lines can be matched across the development of the whole dentition very precisely (Dirks et al. 2002; Schwartz - Dean 2008; FitzGerald - Rose 2008; Hillson 2014). Accentuated lines are nonspecific indicators of stress or illness associated with external disturbances. Although it is known that stress events such as severe deprivation, malnutrition, fevers and infectious diseases or immunizations can leave seri- ous or minor stress markings, it is not possible to say what the accentuated lines represent for an individual specifically without knowing their clinical history (Dean - Elamin 2014; Birch - Dean 2014). An exception is the neonatal line, one specific, very prominent accentuated line observable in all deciduous teeth and in the first permanent molars which is directly linked to the time of birth (Hillson 2014).

Odontochronological analyses of growth markers and accentuated (stress) lines in enamel and dentine (Fig. 1) make it possible to reliably reconstruct a chronology of dental development and timing of stressful events from histological sections of teeth (FitzGerald - Rose 2008). In dentally immature individuals, besides the stress chronology, the sequence of subsequent accentuated lines ending with the last-formed increment on the least developed tooth can be used to assess chronological age at death (Dean - Beynon 1991; Dirks 1998; Reid et al. 1998; Thomas 2003; Smith - Reid - Sirianni 2006; Smith 2008; Schwartz - Dean 2008; Antoine - Hillson - Dean 2009; Hillson 2014).

The purpose of this study was to outline possible applications of odontochronological techniques in bioarchaeology using the example of retrieval of a developmental record from dental remains of a child's skeleton from a solitary burial found in a site Muráň-Castle, Slovakia (Fig. 2). According to archaeological evidence, it is unlikely that the remains belong to the Renaissance or Baroque periods. They could be dated to the Late Bronze Age, however the method of burial is not typical (Malček - Šimkovic 2013). Histological study of the dental remains of this individual was motivated in part by the presence of visual stress indicators (dental enamel hypoplasia, slightly expressed cribra orbitalia), but also by absence of Harris lines which are likewise used as indicators of stress in past populations (Larsen 2002).

We carried out a detailed analysis of two deciduous (FDI codes 65, 75) and six permanent teeth (FDI codes 11, 12, 33, 26, 27, 47). Anterior teeth were sectioned longitudinally in the labio-lingual plane, molars in bucco-lingual plane through mesial and distal cusps using a diamond blade (StruersDiscoplan-TS 
cutting machine, cutting disc $200 \mu \mathrm{m})$. The sections were lapped and polished to a final thickness of approximately $100 \mu \mathrm{m}$ on a Struers LaboPol 21 grinder and by hand on a glass plate with an abrasive compound mixed with water, then ultrasonically cleaned, dehydrated in alcohol, and mounted in Canada balsam. Histological tooth thin sections were examined using polarized light microscopy. Observations were made with a Nikon Eclipse 50i transmitted light microscope. Digital images were captured with a NikonDS-Fil microscope camera attached to the microscope using NIS-Elements 3.0 image analysis software. Low-power images at $20 \times$ or $40 \times$ magnification were made for identifying accentuated lines; mid-power images at $100 \times$ magnification for taking measurements along enamel prisms/dentin tubules; and high-power images at $200 \times$ or $400 \times$ magnification for taking measurements of daily increments. High resolution digital photomontages of the entire tooth section and particular parts of enamel and dentine were created using Adobe Photoshop. Measurements were captured from these photomontages and highpower images using SigmaScan Pro 5.0 software.

Each section was analysed to determine the number of days between accentuated lines beginning from the neonatal line in the deciduous teeth. Intervals between them and ages at their formation were obtained by calculation using measurements of the distance between adjacent accentuated lines along prisms/dentine tubules and measurements of the mean daily secretion rate in that area rather than by counting daily increments as they were mostly obscured and could not be counted completely (Dirks et al. 2010; Dirks - Bromage - Agenbroad 2012).

Identification of the neonatal line in all deciduous teeth and the overlap of subsequent accentuated lines (Fig. 3) allowed creating chronology of dental development, i.e. chronological ages of crown initiation and completion (Tab. 1), as well as assessing chronological ages of stress episodes (Tab. 2). Partially developed root of the second molars allowed assessing age at death (Tab. 2). In total more than 30 accentuated lines were identified in teeth. Figure 4 illustrates histological reconstruction of the developmental history of this individual from birth to death. The first accentuated line identified in the deciduous molars can be confidently interpreted as the neo- natal line, which marks the event of birth. During the first year of postnatal life, the most prominent accentuated lines occurred around the age of 8-11 months. During the second year of postnatal life, this individual experienced a high frequency of stress, and around the age of 2 and 3.5 years, a prolonged period of stress that persisted for a longer time and manifested in the anterior teeth crown surface as hypoplastic defects. After that, the most prominent accentuated lines occurred in the life of this individual around the age of 4.5 years. There were observed no such prominent accentuated lines during the last one and a half years of life of this individual. The age at formation of the last-formed increment, and thus the age at death (Fig. 5) of this individual, was determined as 6.7 years (within the range from 6.4 to 7 years when minimal and maximal values of all measurements from different teeth performed in cuspal enamel and dentine were used for calculation).

The high frequency of accentuated lines visible in histological sections of teeth shows that hypoplastic defects represent only the most visible part of a wide spectrum of the experienced stressful events, which, moreover, are very difficult to record by simple observation of crown surface with the naked eye. Although it is not possible to say what the accentuated lines (except for the neonatal line) represent for an individual without having medical records (Dean Elamin 2014; Birch - Dean 2014), our findings suggest that this individual was exposed to significant physiological disturbances throughout the whole life in contrast to indications of osteological stress markers. The absence of Harris lines suggest that there are other factors responsible for their occurrence than those causing the formation of stress markings in the microstructure of teeth. However, it is possible that Harris lines are more likely a result of normal growth and growth spurts, rather than a pure outcome of nutritional or pathologic stress (Papageorgopoulou et al. 2011). Cribra orbitalia indicates that this individual experienced some kind of chronic health problem, not necessarily anemia (Wapler - Crubézy - Schultz 2004), but they are only slightly expressed and pseudopathology cannot be excluded without histological examination.

The incremental manner of dental development with a daily clock embedded in the microstructure of 
teeth, ability of teeth to record physiological upsets and stressful events during the formation of dental tissues and to preserve these records for as long as the tooth exists enable to reconstruct much information from the life history of an individual using the method of odontochronology. By including the histological approach and analysis of tooth sections in the study of past populations, it is possible to obtain an independent chronology of dental development without relying on the reference collections or modern dental developmental standards; retrieve a more complete picture about stress experienced during development than in studies based only on the external inspection of teeth or radiology; obtain an independent assessment of age at death in skeletal remains of sub-adults whose dentitions were still forming at the time of death; and get more in-depth information about the life of people from the past.

\section{Mgr. Adela Hupková}

- Laboratoř morfologie a forenzní antropologie, Ústav antropologie, Přírodovědecká fakulta, Masarykova univerzita, Kotlářská 2, 61137 Brno hupkova@sci.muni.cz

\section{Bc. Soňa Šáliová}

- Laboratoř morfologie a forenzní antropologie, Ústav antropologie, Prírodovědecká fakulta, Masarykova univerzita, Kotlářská 2, 61137 Brno s.saliova@hotmail.com

\section{doc. RNDr. Miroslav Králík, Ph.D.}

- Laboratoř morfologie a forenzní antropologie, Ústav antropologie, Př́rodovědecká fakulta, Masarykova univerzita, Kotlářská 2, 61137 Brno mirekkralik@seznam.cz

\section{Mgr. Róbert Malček, Ph.D.}

- Archeologický ústav Slovenská akadémia vied Vysunuté pracovisko Zvolen, Štúrová 2, 960 53, Zvolen, Slovenská republika malcek@savzv.sk 